\title{
Ocorrência de Fe-Ti-V associado ao Magmatismo Gabro-Anortosítico da Serra da Alegria, Maciço Rio Apa, Mato Grosso do Sul

\author{
Fe-Ti-Voccurrence associated to Serra da Alegria \\ Gabbro-Anortosite Magmatism, Rio Apa Massif, Mato Grosso do Sul
}

\author{
Antonio Misson Godoy ${ }^{1}$ (D), Otávio Augusto Ruiz Paccola Vieira² (D), Larissa Marques Barbosa de Araújo ${ }^{3}$ \\ George Luiz Luvizotto ${ }^{1}$ (D), Jefferson Cassu Manzano ${ }^{4}$ \\ "Universidade Estadual Paulista "Júlio de Mesquita Filho" - UNESP, Instituto de Geociências e Ciências Exatas - IGCE, \\ Departamento de Petrologia e Metalogenia - DPM, Avenida 24A, 1515, Bela Vista, CEP 13 506-900, \\ Rio Claro, SP, BR (antonio.godoy@unesp.br; george.luvizotto@rc.unesp.br) \\ 2UNESP, IGCE, Pós-Graduação em Geociências, Rio Claro, SP, BR (otaviovieirageo@gmail.com) \\ 3Universidade Federal de Uberlândia - UFU, Instituto de Geografia - IG, Curso de Geologia, \\ Monte Carmelo, MG, BR (larissamarquesba@gmail.com) \\ ${ }^{4}$ Mineração Rio Tinto, Brasília, DF, BR (manzanojc@gmail.com)
}

Recebido em 8 de agosto de 2018; aceito em 16 de dezembro de 2019

\begin{abstract}
Resumo
O Maciço Rio Apa constitui exposições de rochas paleoproterozoicas na porção extremo sul do Cráton Amazônico. A região é constituída por rochas do Complexo Rio Apa, Grupo Alto Tererê e pelo Grupo Amonguijá, formado pelas suítes Vulcânica Serra da Bocaina e Plutônica do Batólito Alumiador. O segmento norte do batólito é caracterizado por rochas ácidas-básicas da Serra da Alegria, ocorrendo, na parte central, rochas da Sequência Magmática Ácida-Intermediária, representadas pelo granito homônimo. No seu entorno, no sopé das escarpas, aflora a Sequência Magmática Gabro-Anortosítica da Serra da Alegria, composta por magnetita gabro, quartzo gabro a leuco gabro, pegmatito básico e anortosito. Essas rochas gabroides constituem uma ocorrência magmática, cumulática básica, estratiforme, semiconcordante, formada por processos de cristalização fracionada, por flotação dos plagioclásios em anortosito, nas porções superiores da câmara magmática e, na parte inferior, por segregação gravítica, a concentração de cumulus de óxido de ferro constitui magnetita gabro e magnetitito. Os minerais magmáticos identificados correspondem a andesina-labradorita, apresentando teor de anortita entre $\mathrm{An}_{36,76}$ $\mathrm{An}_{58,06}$ e clinopiroxênio cálcico do tipo ferro-augita e augita. Os óxidos de ferro predominantes são ferromagnetita, com valores de $\mathrm{FeO}^{\mathrm{t}}$ entre 88,03 e 92,98\%, e titanomagnetita, com valores de $\mathrm{TiO}_{2}$ entre 1,13 e 6,39\%. As fases subordinadas são representadas por vanádio magnetita, com valores de $\mathrm{V}_{2} \mathrm{O}_{5}$ entre 0,75 e $0,98 \%$, e ilmenita. O magmatismo básico-anortosítico sin a pós-orogênico foi resultado da cristalização de um magma mantélico primário que, associado a processos de diferenciação, gerou variedades de gabros e diabásios de composições Fe-toleíticas e diferenciados anortosíticos, em ambientes de arco de ilha a intraplaca.
\end{abstract}

Palavras-chave: Maciço Rio Apa; Serra da Alegria; Gabro-anortosito; Química mineral.

\begin{abstract}
The Rio Apa Massif is defined by the exposition of paleoproterozoic rocks in the extreme southern portion of the Amazonian Craton. The region consists of rocks from the Rio Apa Complex, Alto Tererê Group, and the Amonguijá Group, which are identified by the Serra da Bocaina Volcanic Suite and Alumiador Plutonic Suite. The northern batholith segment is characterized by acid-basic Serra da Alegria rocks, which is composed in its central part of the Serra da Alegria Acid-Intermediate Magmatic Sequence, identified by the homonymous Granite. In its surroundings, at the cliffs' foothills, the Serra da Alegria Gabbro-Anorthositic Magmatic Sequence outcrops, composed by magnetite gabbro, quartz gabbro to leucogabbro, basic pegmatite and anorthosite. In marginal areas, constituting the foothills of the cliffs, the Serra da Alegria Gabbro-Anorthosite Magmatic Sequence is composed of magnetite gabbro, quartz gabbro, leucogabbro, basic pegmatite and anorthosite. These gabbroid rocks constitute a semi-concordant stratiform basic cumulated magmatic deposit generated from fractional crystallization processes by gravitational segregation, resulting in the formation of anorthosite in the upper
\end{abstract}


portions of the magma chamber. In the lower part, segregation of iron oxides cumulus constituted magnetite gabbro and magnetite rocks. The magmatic minerals are andesine-labradorite, with anorthite content between $\mathrm{An}_{36,76}$ to $\mathrm{An}_{58,06}$ and calcic clinopyroxene, as augite and iron-augite type. Iron oxides are predominantly ferromagnetite, with $\mathrm{FeO}^{\mathrm{t}}$ values between 88.03 and $92.98 \%$, and titanium magnetite with $\mathrm{TiO}_{2}$ values between 1.13 and $6.39 \%$. Subordinate oxide phases consist of vanadium magnetite, with values of $\mathrm{V}_{2} \mathrm{O}_{5}$ between 0.75 and $0.98 \%$, and ilmenite. The syn- to post-orogenic basic-anorthositic magmatism evolution was the result of the crystallization of a primary mantle magma, which, associated with differentiation processes, generated a variety of gabbro and diabase varieties of anorthositic Fe-toleitic and differentiated compositions, in island arc to intraplate environments.

Keywords: Rio Apa Massif; Serra da Alegria; Gabbro-anorthosite; Mineral chemistry.

\section{INTRODUÇÃO}

O extremo sul do Cráton Amazônico é caracterizado pelas rochas paleoproterozoicas do Maciço Rio Apa, localizado na região sudoeste do Estado de Mato Grosso do Sul, ao oeste dos contrafortes da Serra da Bodoquena, no município de Porto Murtinho. As rochas encontram-se expostas nas principais serras que se elevam em áreas de relevo arrasado do Domínio da Depressão do Rio Paraguai, e encontram-se parcialmente encobertas ao oeste e ao norte pelos sedimentos da Bacia Sedimentar do Pantanal.

A região foi descrita em Godoy et al. (2009a) e é composta de rochas ortoderivadas do Complexo Rio Apa, rochas metassedimentares do Grupo Alto Tererê e rochas do Grupo Amonguijá, identificadas pelas suítes Vulcânica Serra da Bocaina (Godoy et al., 2010) e Plutônica Alumiador (Godoy et al., 2006; Manzano et al., 2012). A Figura 1 apresenta os mapas da área, mantendo as subdivisões e as terminologias propostas das unidades mapeadas por Godoi et al. (2001) e Godoy et al. (2009a) (Figura 1A).

As rochas da Suíte Plutônica Alumiador constituem o Batólito Alumiador (Godoy et al., 2006, 2009a; Manzano et al., 2012), que se dispõe na forma alongada segundo a direção geral N-S e se encontra seccionado por falhamentos de direção NW, o que permite compartimentá-lo em quatro segmentos principais de serras: o segmento sul, denominado de Serra da Esperança; os centrais, que incluem as serras de Alumiador e do Catimbaté; e o do norte, correspondente à Serra da Alegria, na qual localiza-se a área de estudo (Figura 1B).

O segmento norte é representado por duas sequências magmáticas: uma caracterizada pelo Granito Serra da Alegria, de composição intermediária-ácida e denominada de Sequência Magmática Ácida-Intermediária da Serra da Alegria, e, a outra, de composição básica-ultrabásica, denominada de Sequência Magmática Gabro-Anortosítica da Serra da Alegria (Godoy et al., 2014).

O primeiro trabalho geológico e geoquímico sobre as ocorrências litológicas básicas-ácidas da Serra da Alegria, em escala de 1:100.000, foi realizado na parte extremo sul da serra por Silva (1998), que denominou essas rochas de
"Intrusão Diferenciada Gabro-Anortosito Granofíricas da Serra da Alegria".

Essa ocorrência foi descrita no Mapa Geológico do Estado de Mato Grosso do Sul em escala 1:1.000.000, por Lacerda Filho et al. (2006), nos trabalhos de cunho geológico e geoquímico de Godoy et al. $(2006,2010)$ e Manzano et al. (2012) e nos trabalhos do magmatismo da Serra da Alegria, por Godoy et al. (2009a, 2014). Recentemente, o Granito Serra Alegria foi denominado de Granito Aquidabã, por Nogueira et al. (2013), e de Granito Santa Otília, por Pavan et al. (2014) e Faleiros et al. (2015). Trabalhos com enfoque geocronológico específico nas rochas da Serra da Alegria foram desenvolvidos por Lacerda Filho et al. (2006), Silva et al. (2008), Cordani et al. (2010), Faleiros et al. (2015), Nogueira et al. (2013) e Lacerda Filho (2015).

Este artigo caracteriza o Magmatismo Grabro-Anortosítico da Serra da Alegria com enfoque principal nas suas concentrações de óxidos de ferro e na associação de ferro-titânio-vanádio. O objetivo é ampliar o conhecimento sobre essa sequência magmática, a partir de novos dados geológicos, geoquímicos, petrográficos e de química mineral, de modo a identificar o seu potencial mineral.

\section{MATERIAIS E MÉTODOS}

As 16 amostras de rochas básicas representativas do magmatismo Gabro-Anortosítico foram analisadas nos laboratórios do Departamento de Petrologia e Metalogenia (DPM), da Universidade Estadual Paulista "Júlio de Mesquita Filho" (UNESP) - Campus de Rio Claro.

As análises químicas qualitativas e semiquantitativas foram realizadas no Laboratório de Microscopia Eletrônica, utilizando-se microscópico eletrônico de varredura (MEV), modelo JEOL-JSM-6010LA, com detector de energy dispersive X-ray spectrometer (EDS) acoplado. Análises químicas quantitativas foram realizadas no Laboratório de Microssonda Eletrônica do DPM, utilizando-se microssonda eletrônica (EPMA), modelo JEOL JXA8230 Superprobe, com cinco detectores WDS. As análises encontram-se nas Tabelas 1,2 e 3, e foram realizadas em amostras de 


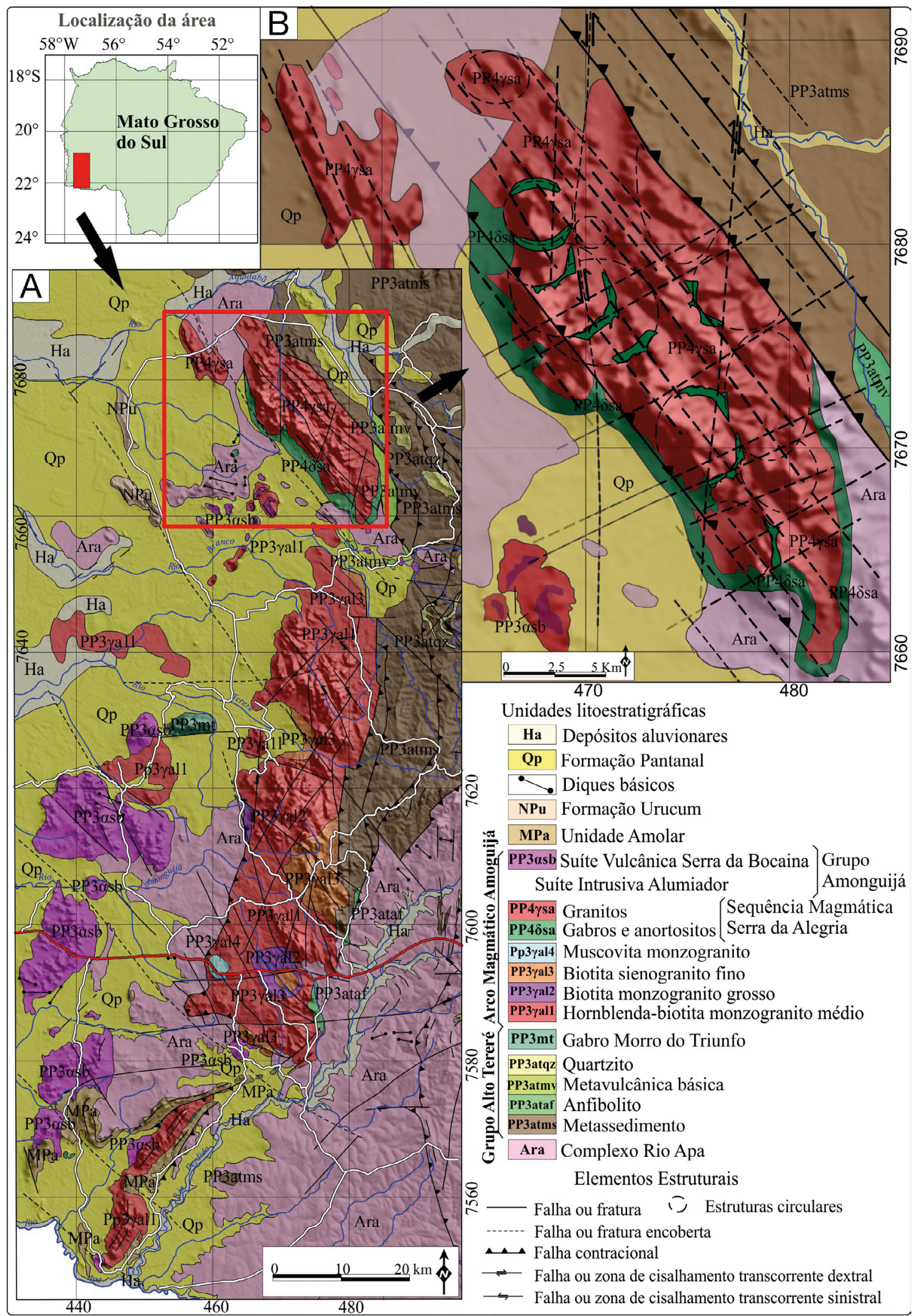

Figura 1. (A) Modelo digital de terreno do Batólito Alumiador, com destaque para a Serra da Alegria (Godoy et al., 2009a; Manzano et al., 2012). (B) Mapa geológico da Serra da Alegria, sobreposto ao modelo digital de terreno SRTM (Godoy et al., 2014). 
magnetita, titanomagnetita, ilmenita, plagioclásio e piroxênio, bem como obtidas imagens de elétrons retroespalhados (BSE).
As análises de química mineral foram realizadas em lâminas delgadas-polidas recobertas com fina camada de carbono $(250 \AA)$ sob condições analíticas de $15 \mathrm{kV}$

Tabela 1. Análise química quantitativa de plagioclásio obtida em microssonda eletrônica de rochas da Sequência Magmática Gabro-Anortosítica da Serra da Alegria.

\begin{tabular}{|c|c|c|c|c|c|c|c|c|c|c|c|c|}
\hline Amostra & plg_1 & plg_2 & plg_3 & plg_4 & plg_5 & plg_6 & plg_7 & plg_8 & plg_9 & plg_10 & plg_11 & plg_12 \\
\hline $\mathrm{SiO}_{2}$ & 56,12 & 57,17 & 63,71 & 64,45 & 64,38 & 66,25 & 53,83 & 52,75 & 53,24 & 53,83 & 53,24 & 54,33 \\
\hline $\mathrm{Al}_{2} \mathrm{O}_{3}$ & 28,37 & 27,93 & 22,94 & 22,62 & 22,20 & 22,06 & 29,46 & 29,35 & 29,11 & 29,44 & 29,70 & 29,29 \\
\hline $\mathrm{Fe}_{2} \mathrm{O}_{3}$ & 0,64 & 0,55 & 0,17 & 0,32 & 0,14 & 0,47 & 0,56 & 0,88 & 0,95 & 0,58 & 0,74 & 0,60 \\
\hline $\mathrm{CaO}^{3}$ & 8,18 & 7,41 & 2,22 & 1,29 & 2,82 & 1,35 & 11,39 & 11,80 & 11,69 & 11,40 & 11,94 & 11,32 \\
\hline $\mathrm{Na}_{2} \mathrm{O}$ & 5,86 & 6,44 & 9,61 & 9,86 & 9,98 & 10,41 & 5,07 & 4,56 & 4,83 & 4,95 & 4,61 & 5,00 \\
\hline $\mathrm{K}_{2} \mathrm{O}$ & 1,02 & 0,93 & 0,71 & 1,18 & 0,06 & 0,74 & 0,18 & 0,23 & 0,17 & 0,23 & 0,24 & 0,25 \\
\hline Total & 100,19 & 100,43 & 99,35 & 99,72 & 99,58 & 101,27 & 100,49 & 99,58 & 99,99 & 100,43 & 100,47 & 100,80 \\
\hline $\mathrm{Si}$ & 2,52 & 2,55 & 2,83 & 2,85 & 2,85 & 2,88 & 2,42 & 2,40 & 2,42 & 2,43 & 2,40 & 2,44 \\
\hline $\mathrm{Al}$ & 1,50 & 1,47 & 1,20 & 1,18 & 1,16 & 1,13 & 1,56 & 1,58 & 1,56 & 1,56 & 1,58 & 1,55 \\
\hline $\mathrm{Fe}$ & 0,02 & 0,02 & 0,01 & 0,01 & 0,00 & 0,02 & 0,02 & 0,03 & 0,03 & 0,02 & 0,03 & 0,02 \\
\hline $\mathrm{Ca}$ & 0,39 & 0,35 & 0,11 & 0,06 & 0,13 & 0,06 & 0,55 & 0,58 & 0,57 & 0,55 & 0,58 & 0,54 \\
\hline $\mathrm{Na}$ & 0,51 & 0,56 & 0,83 & 0,85 & 0,86 & 0,88 & 0,44 & 0,40 & 0,42 & 0,43 & 0,40 & 0,44 \\
\hline K & 0,06 & 0,05 & 0,04 & 0,07 & 0,00 & 0,04 & 0,01 & 0,01 & 0,01 & 0,01 & 0,01 & 0,01 \\
\hline Soma Cátions & 5,00 & 5,01 & 5,00 & 5,01 & 5,00 & 5,01 & 5,01 & 5,00 & 5,01 & 5,01 & 5,00 & 5,00 \\
\hline $\mathrm{Ab}$ & 53,00 & 57,77 & 85,00 & 86,88 & 86,23 & 89,43 & 44,18 & 40,59 & 42,36 & 43,40 & 40,58 & 43,78 \\
\hline An & 40,90 & 36,76 & 10,86 & 6,26 & 13,45 & 6,41 & 54,80 & 58,04 & 56,64 & 55,26 & 58,06 & 54,76 \\
\hline Or & 6,10 & 5,47 & 4,14 & 6,86 & 0,32 & 4,16 & 1,02 & 1,36 & 1,00 & 1,33 & 1,36 & 1,45 \\
\hline Mineral & \multicolumn{2}{|c|}{ andesina } & \multicolumn{4}{|c|}{ albita } & \multicolumn{6}{|c|}{ labradorita } \\
\hline
\end{tabular}

Tabela 2. Análises químicas quantitativas de piroxênios obtidas em microssonda eletrônica de rochas da Sequência Magmática Gabro-Anortosítica da Serra da Alegria.

\begin{tabular}{|c|c|c|c|c|c|c|c|c|c|c|}
\hline Amostra & px_1 & px_2 & px_3 & px_4 & px_5 & px_6 & px_7 & px_8 & px_9 & px_10 \\
\hline $\mathrm{SiO}_{2}$ & 49,69 & 49,59 & 52,74 & 51,84 & 52,00 & 50,89 & 51,45 & 49,45 & 50,85 & 49,95 \\
\hline $\mathrm{TiO}_{2}$ & 0,64 & 0,64 & 0,10 & 0,02 & 0,03 & 0,66 & 0,00 & 0,56 & 0,00 & 0,00 \\
\hline $\mathrm{Al}_{2} \mathrm{O}_{3}$ & 2,96 & 3,17 & 2,13 & 2,13 & 3,15 & 2,35 & 0,68 & 4,35 & 0,77 & 1,10 \\
\hline $\mathrm{Cr}_{2} \mathrm{O}_{3}$ & 0,00 & 0,00 & 0,01 & 0,02 & 0,00 & 0,01 & 0,00 & 0,00 & 0,00 & 0,00 \\
\hline $\mathrm{FeO}$ & 11,01 & 10,98 & 15,40 & 16,50 & 17,41 & 11,25 & 24,61 & 15,37 & 26,45 & 28,47 \\
\hline $\mathrm{MnO}$ & 0,27 & 0,30 & 0,20 & 0,21 & 0,24 & 0,31 & 0,52 & 0,24 & 0,59 & 0,68 \\
\hline $\mathrm{MgO}$ & 13,75 & 13,69 & 13,63 & 12,59 & 12,24 & 14,82 & 7,77 & 13,44 & 6,36 & 4,98 \\
\hline $\mathrm{CaO}$ & 19,52 & 19,46 & 11,88 & 12,15 & 12,05 & 18,27 & 11,70 & 11,35 & 11,60 & 11,74 \\
\hline $\mathrm{Na}_{2} \mathrm{O}$ & 0,28 & 0,32 & 0,26 & 0,37 & 0,52 & 0,26 & 0,10 & 0,92 & 0,12 & 0,12 \\
\hline $\mathrm{K}_{2} \mathrm{O}$ & 0,01 & 0,00 & 0,03 & 0,06 & 0,08 & 0,00 & 0,03 & 0,24 & 0,02 & 0,06 \\
\hline Total & 98,15 & 98,16 & 96,39 & 95,89 & 97,72 & 98,81 & 96,86 & 95,92 & 96,75 & 97,10 \\
\hline $\mathrm{Si}$ & 1,90 & 1,90 & 2,03 & 2,02 & 2,00 & 1,93 & 2,07 & 1,93 & 2,07 & 2,05 \\
\hline $\mathrm{Ti}$ & 0,02 & 0,02 & 0,00 & 0,00 & 0,00 & 0,02 & 0,00 & 0,02 & 0,00 & 0,00 \\
\hline $\mathrm{Cr}$ & 0,00 & 0,00 & 0,00 & 0,00 & 0,00 & 0,00 & 0,00 & 0,00 & 0,00 & 0,00 \\
\hline Mg & 0,78 & 0,78 & 0,78 & 0,73 & 0,70 & 0,84 & 0,47 & 0,78 & 0,38 & 0,30 \\
\hline $\mathrm{Fe}$ & 0,35 & 0,35 & 0,50 & 0,54 & 0,56 & 0,36 & 0,83 & 0,50 & 0,90 & 0,98 \\
\hline $\mathrm{Mn}$ & 0,01 & 0,01 & 0,01 & 0,01 & 0,01 & 0,01 & 0,02 & 0,01 & 0,02 & 0,02 \\
\hline $\mathrm{Ca}$ & 0,80 & 0,80 & 0,49 & 0,51 & 0,50 & 0,74 & 0,50 & 0,47 & 0,50 & 0,52 \\
\hline $\mathrm{Na}$ & 0,02 & 0,02 & 0,02 & 0,03 & 0,04 & 0,02 & 0,01 & 0,07 & 0,01 & 0,01 \\
\hline Soma Cations & 4,02 & 4,02 & 3,93 & 3,94 & 3,95 & 4,01 & 3,92 & 3,98 & 3,92 & 3,93 \\
\hline Wo & 41,31 & 41,34 & 27,72 & 28,56 & 28,25 & 38,34 & 28,05 & 27,01 & 28,23 & 28,71 \\
\hline En & 40,49 & 40,45 & 44,23 & 41,17 & 39,91 & 43,25 & 25,91 & 44,46 & 21,52 & 16,93 \\
\hline Fs & 18,20 & 18,20 & 28,04 & 30,28 & 31,84 & 18,41 & 46,04 & 28,53 & 50,25 & 54,35 \\
\hline Mineral & \multicolumn{10}{|c|}{ piroxênio } \\
\hline
\end{tabular}


e $20 \mathrm{nA}$ em minerais silicáticos formadores de rocha e $100 \mathrm{nA}$ e $20 \mathrm{kV}$ em elementos-traço nos óxidos de ferro (limites de detecção em ppm-2 sigma: Si 60; $\mathrm{Al} 40 ; \mathrm{Mg}$ 40; V 70; Cr 70; Mn 80; Fe 100; Ni 60; Cu 65; Ti 50; $\mathrm{Nb} 120 ; \mathrm{Zr} 100)$.

A padronização foi feita em minerais, óxidos e metais puros, dependendo do elemento a ser analisado. A correção de matriz (ZAF) foi feita online, utilizando-se o software da JEOL. Para as análises de plagioclásio e piroxênio, utilizou-se tempo de contagem de 10 segundos no pico e 5 segundos em cada posição do background (inferior e superior).

Para a magnetita, a titanomagnetita e a ilmenita, a tensão de aceleração foi ajustada para $20 \mathrm{kV}$ e corrente de amostra para $80 \mathrm{nA}$. Os seguintes elementos foram analisados: $\mathrm{Si}, \mathrm{Al}, \mathrm{Cr}, \mathrm{V}, \mathrm{Mg}, \mathrm{Mn}, \mathrm{Cu}, \mathrm{Ni}, \mathrm{Fe}, \mathrm{Ti}, \mathrm{Nb}$ e $\mathrm{Zr}$. A interferência entre $\mathrm{V}(\mathrm{Ka})$ e $\mathrm{Ti}(\mathrm{K} \beta)$ foi corrigida online com base em análise de padrões (rutilo sintético e V metal). Intensidades foram corrigidas previamente à correção de matriz.

As análises químicas de rocha total e multielementar para elementos maiores, menores, traço e terras raras (ETR) foram realizadas no Laboratório de Geoquímica (LABOGEO), sendo utilizada fluorescência de raios X para os elementos maiores (concentração em \%), por intermédio de pastilha fundida em meio borato, e para os elementos-traço (concentração em ppm), por meio de pastilha prensada. A determinação dos ETR (em ppm) foi feita por espectrometria de emissão atômica por plasma indutivamente acoplado (Inductively Coupled Plasma-Atomic Emission Spectrometry - ICP-AES), segundo os padrões de rotina do laboratório (Malagutti et al., 1998). As análises encontram-se enumeradas na Tabela 4 e descritas em Godoy et al. (2014).

Tabela 3. Análise química quantitativa de espinélios nos gabros em microssonda eletrônica de rochas da Sequência Magmática Gabro-Anortosítica da Serra da Alegria.

\begin{tabular}{|c|c|c|c|c|c|c|c|c|c|c|c|c|c|c|}
\hline & Mag1 & Mag2 & Mag3 & Mag4 & Mag5 & IIm1 & IIm2 & IIm3 & IIm4 & IIm5 & Titmag1 & Titmag2 & Titmag3 & Titmag 4 \\
\hline $\mathrm{SiO}_{2}$ & 0,02 & 0,02 & 0,19 & 0,00 & 0,02 & 0,00 & 0,20 & 0,00 & 0,00 & 0,01 & 0,06 & 0,02 & 0,04 & 0,01 \\
\hline $\mathrm{TiO}_{2}$ & 2,94 & 1,13 & 1,62 & 6,39 & 3,45 & 51,58 & 43,95 & 53,07 & 53,10 & 52,26 & 10,53 & 18,76 & 11,26 & 13,57 \\
\hline $\mathrm{Al}_{2} \mathrm{O}_{3}$ & 0,48 & 0,28 & 0,08 & 0,31 & 0,37 & 0,05 & 1,52 & 0,00 & 0,01 & 0,01 & 1,43 & 0,55 & 0,75 & 0,51 \\
\hline FeOt & 90,76 & 92,90 & 91,98 & 88,03 & 90,68 & 46,83 & 50,87 & 46,04 & 45,83 & 46,51 & 83,22 & 75,82 & 81,87 & 81,54 \\
\hline $\mathrm{MnO}$ & 0,11 & 0,04 & 0,01 & 0,26 & 0,14 & 2,09 & 1,87 & 2,19 & 2,18 & 2,17 & 0,47 & 0,81 & 0,52 & 0,60 \\
\hline $\mathrm{MgO}$ & 0,02 & 0,01 & 0,04 & 0,00 & 0,02 & 0,06 & 0,18 & 0,04 & 0,04 & 0,04 & 0,04 & 0,03 & 0,03 & 0,01 \\
\hline $\mathrm{Cr}_{2} \mathrm{O}_{3}$ & 0,05 & 0,06 & 0,08 & 0,08 & 0,08 & 0,01 & 0,02 & 0,00 & 0,00 & 0,01 & 0,05 & 0,04 & 0,04 & 0,07 \\
\hline $\mathrm{V}_{2} \mathrm{O}_{3}$ & 0,81 & 0,87 & 0,75 & 0,97 & 0,98 & 0,24 & 0,34 & 0,16 & 0,13 & 0,20 & 0,74 & 0,65 & 0,73 & 0,86 \\
\hline $\mathrm{CuO}$ & 0,00 & 0,00 & 0,00 & 0,00 & 0,00 & 0,00 & 0,00 & 0,00 & 0,00 & 0,00 & 0,00 & 0,00 & 0,00 & 0,00 \\
\hline $\mathrm{NiO}$ & 0,01 & 0,01 & 0,01 & 0,01 & 0,01 & 0,00 & 0,00 & 0,00 & 0,00 & 0,00 & 0,00 & 0,00 & 0,01 & 0,01 \\
\hline $\mathrm{ZrO}_{2}$ & 0,01 & 0,00 & 0,00 & 0,01 & 0,00 & 0,09 & 0,01 & 0,00 & 0,00 & 0,01 & 0,00 & 0,00 & 0,01 & 0,00 \\
\hline $\mathrm{Nb}_{2} \mathrm{O}_{5}$ & 0,00 & 0,00 & 0,00 & 0,00 & 0,00 & 0,00 & 0,00 & 0,00 & 0,00 & 0,00 & 0,00 & 0,00 & 0,00 & 0,00 \\
\hline Total & 95,20 & 95,31 & 94,78 & 96,06 & 95,75 & 100,96 & 98,96 & 101,50 & 101,30 & 101,23 & 96,55 & 96,68 & 95,27 & 97,17 \\
\hline Si (ppm) & 96 & 78 & 903 & $\mathrm{BD}$ & 98 & $\mathrm{BD}$ & 932 & $\mathrm{BD}$ & $\mathrm{BD}$ & 62 & 288 & 84 & 199 & $\mathrm{BD}$ \\
\hline Ti (ppm) & 17.655 & 6.747 & 9.737 & 38.306 & 20.705 & 309.245 & 263.510 & 318186 & 318.352 & 313.326 & 63.099 & 112493 & 67.517 & 81.372 \\
\hline Al (ppm) & 2.529 & 1.480 & 441 & 1.626 & 1.973 & 285 & 8.052 & $\mathrm{BD}$ & $\mathrm{BD}$ & $\mathrm{BD}$ & 7.584 & 2888 & 3.971 & 2.698 \\
\hline Cr (ppm) & 351 & 405 & 573 & 529 & 571 & 86 & 124 & $\mathrm{BD}$ & $\mathrm{BD}$ & 57 & 344 & 261 & 307 & 485 \\
\hline $\mathrm{Fe}$ (ppm) & 705.450 & 722.126 & 714.965 & 684.278 & 704.874 & 364.028 & 395.414 & 357.866 & 356.259 & 361.535 & 646.883 & 58.9343 & 636.400 & 63.3798 \\
\hline Mn (ppm) & 882 & 293 & 108 & 2041 & 1.085 & 16.201 & 14.469 & 16.965 & 16.882 & 16.798 & 3.648 & 6.310 & 4.049 & 4.632 \\
\hline Mg (ppm) & 103 & $\mathrm{BD}$ & 256 & $\mathrm{BD}$ & 103 & 335 & 1.096 & 247 & 220 & 243 & 247 & 165 & 189 & $\mathrm{BD}$ \\
\hline V (ppm) & 4.955 & 5370 & 4.602 & 5.932 & 6.027 & 1.457 & 2.117 & 954 & 806 & 1.253 & 4.542 & 3.994 & 4.508 & 5.259 \\
\hline $\mathrm{Cu}$ (ppm) & BD & $\mathrm{BD}$ & $\mathrm{BD}$ & $\mathrm{BD}$ & $\mathrm{BD}$ & $\mathrm{BD}$ & $\mathrm{BD}$ & $\mathrm{BD}$ & $\mathrm{BD}$ & $\mathrm{BD}$ & BD & $\mathrm{BD}$ & $\mathrm{BD}$ & BD \\
\hline $\mathrm{Ni}(\mathrm{ppm})$ & $\mathrm{BD}$ & 97 & 97 & $\mathrm{BD}$ & $\mathrm{BD}$ & $\mathrm{BD}$ & $\mathrm{BD}$ & $\mathrm{BD}$ & $\mathrm{BD}$ & $\mathrm{BD}$ & $\mathrm{BD}$ & $\mathrm{BD}$ & $\mathrm{BD}$ & $\mathrm{BD}$ \\
\hline Zr (ppm) & BD & $\mathrm{BD}$ & BD & 54 & $\mathrm{BD}$ & 634 & $\mathrm{BD}$ & $\mathrm{BD}$ & BD & 67 & $\mathrm{BD}$ & $\mathrm{BD}$ & $\mathrm{BD}$ & $\mathrm{BD}$ \\
\hline $\mathrm{Nb}$ (ppm) & $\mathrm{BD}$ & $\mathrm{BD}$ & $\mathrm{BD}$ & $\mathrm{BD}$ & $\mathrm{BD}$ & $\mathrm{BD}$ & $\mathrm{BD}$ & $\mathrm{BD}$ & $\mathrm{BD}$ & $\mathrm{BD}$ & $\mathrm{BD}$ & $\mathrm{BD}$ & $\mathrm{BD}$ & $\mathrm{BD}$ \\
\hline $\mathrm{TiO}_{2}$ & 3,10 & 1,18 & 1,71 & 6,67 & 3,61 & 52,03 & 45,97 & 53,16 & 53,29 & 52,52 & 11,07 & 19,59 & 11,93 & 14,08 \\
\hline $\mathrm{Fe}_{2} \mathrm{O}_{3}$ & 14,92 & 15,21 & 15,13 & 14,37 & 14,84 & 7,38 & 8,32 & 7,21 & 7,19 & 7,31 & 13,69 & 12,38 & 13,56 & 13,23 \\
\hline $\mathrm{FeO}$ & 81,99 & 83,61 & 83,16 & 78,96 & 81,55 & 40,59 & 45,72 & 39,63 & 39,52 & 40,17 & 75,24 & 68,03 & 74,51 & 72,69 \\
\hline Mineral & & & רagnetita & & & & & ilmenita & & & & titano & gnetita & \\
\hline
\end{tabular}




\section{GEOLOGIA REGIONAL}

A partir da visão de integração da região do Rio Apa ao Cráton Amazônico, o Maciço ou Bloco Rio Apa foi redefinido como a província geocronológica Rio Apa (Ruiz et al., 2005; Lacerda Filho et al., 2006). As unidades litoestratigráficas que afloram no Maciço Rio Apa estão definidas pelo Complexo Rio Apa, Grupo Alto do Tererê e Grupo Amonguijá (Godoi et al., 2001).

Lacerda Filho et al. (2006) subdividiram a Província Rio Apa em compartimentos geotectônicos distintos:
Remanescente de Crosta Oceânica $(2,2-1,95 \mathrm{Ga})$, Arco Magmático Rio Apa (1,95 - 1,87 Ga), Arco Magmático Amonguijá (1,87 - 1,75 Ga) e Intrusivas Básicas (1,78 Ga). Cordani et al. (2010) propuseram, a partir dos dados geocronológicos, a divisão dessa província em dois grandes blocos tectônicos, do leste e do oeste, justapostos a partir de uma zona de sutura de direção geral N-S, há cerca 1,67 Ga.

A unidade ortoderivada mais antiga é o Complexo Rio Apa, definido por Corrêa et al. (1976), Araújo et al. (1982) e Godoi et al. (2001), e compõe as principais rochas do

Tabela 4. Dados geoquímicos das amostras das rochas da Sequência Magmática Gabro-Anortosítica da Serra da Alegria.

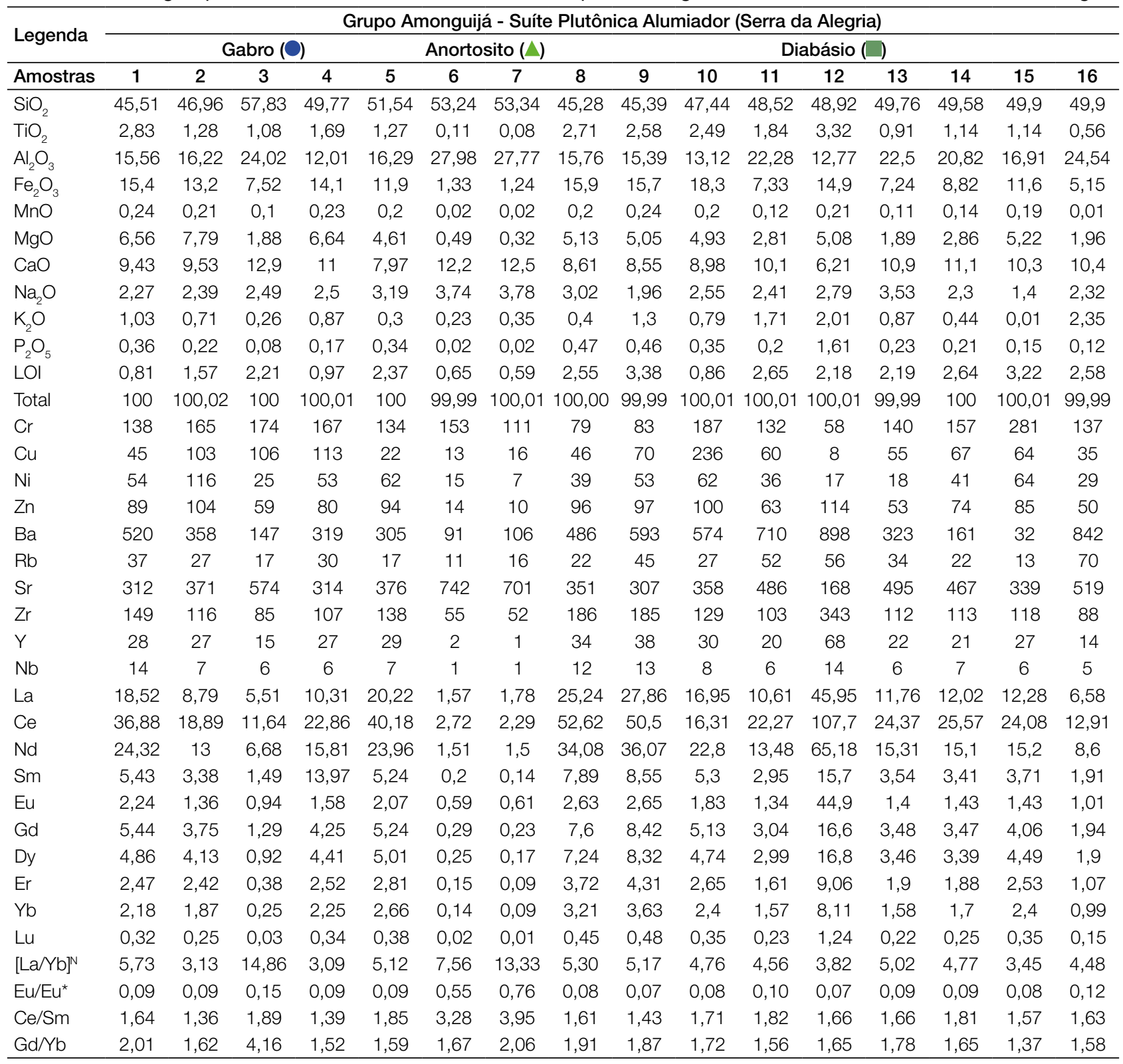


Arco Magmático Rio Apa (Lacerda Filho et al., 2006). Essa unidade ortoderivada recebe a denominação recente de Complexo Porto Murtinho (Lacerda Filho, 2015). É constituída predominantemente de hornblenda-biotita gnaisses e migmatitos de composição ácida a tonalítica, além de raro anfibolito. Associadas a esse conjunto de rochas ortoderivadas ocorrem intercalações tectônicas de rochas paraderivadas, o que sugere a sua correlação a um cinturão metamórfico, mais antigo ou contemporâneo, denominado de Cinturão Metamórfico Rio Apa (Godoy et al., 2009a).

Lacerda Filho et al. (2006) apresentam para as rochas ortoderivadas datações U-Pb em zircão com idade de $1,94 \mathrm{Ga}$, idade modelo $\mathrm{T}_{\mathrm{DM}}$ de $2,57 \mathrm{Ga}$ e valores de $\varepsilon \mathrm{Nd}_{(\mathrm{t})}$ negativos (-6). Cordani et al. (2010), a partir de gnaisse correlatos ao Complexo Rio Apa, apresentaram resultados de datação U-Pb em zircão com idade de $1,95 \mathrm{Ga}$, idade modelo $\mathrm{T}_{\mathrm{DM}}$ de $2,50 \mathrm{Ga}$ e valores de $\varepsilon \mathrm{Nd}_{(\mathrm{t})}$ negativos $(-4,72$ a -5,97). Ambas as datações sugerem a formação de protólitos magmáticos com forte participação de material crustal. Faleiros et al. (2015) obtiveram a idade U-Pb em zircão de $1,91-1,95 \mathrm{Ga}$.

O conjunto de rochas paraderivadas foi descrito por Corrêa et al. (1976), que o denominaram de Associação Metamórfica do Alto Tererê e, posteriormente, por Godoi et al. (2001), de Grupo Alto Tererê. A sequência metavulcanossedimentar constitui uma faixa móvel acrescionária ao Arco Magmático Rio Apa, denominada de Cinturão de Dobramento Alto do Tererê (Godoy et al., 2009a).

Lacerda Filho et al. (2006) adotam o termo Grupo Alto Tererê e consideram a sequência metavulcanossedimentar como pertencente ao compartimento geotectônico Remanescente de Crosta Oceânica, constituindo a unidade mais antiga da área e apresentando para as rochas metabásicas idade modelo $\mathrm{T}_{\mathrm{DM}}$ de 2,26 e $2,28 \mathrm{Ga}$, consideradas próximas às idades de cristalização. Essa interpretação, como a unidade mais antiga, foi revogada por Lacerda Filho (2015), que apresentou idades $\mathrm{U}-\mathrm{Pb}$ em zircão detrítico $(1.72 \mathrm{a}$ 2.12); idade máxima de deposição em $1,72 \mathrm{Ga}$; análises de Sm-Nd com idade modelo de $\mathrm{T}_{\mathrm{DM}} 1,67$; e valores de $\varepsilon \mathrm{Nd}^{(t)}$ negativos (-15.9).

Cordani et al. (2010) apresentaram idade U-Pb em zircão de $1,95 \mathrm{Ga}$, idade modelo $\mathrm{T}_{\mathrm{DM}}$ de $2,26 \mathrm{Ga}$ e valores de $\varepsilon \mathrm{Nd}^{(t)}$ positivos $(+0,09 \mathrm{a}+1,09)$ para gnaisse que foi associado ao Grupo Alto do Tererê. Sugere-se, para os valores de idades obtidas para essa datação, associação ao Complexo Rio Apa.

O conjunto de rochas plutono-vulcânico ácido foi definido inicialmente por Corrêa et al. (1976) e Correia Filho et al. (1981), que o denominaram de Complexo Amonguijá, constituído das suítes Intrusiva Alumiador e Vulcânica Serra da Bocaina. A esse conjunto de rochas denominou-se de Supersuíte Amonguijá (Godoi e Martins, 1999) e Grupo Amonguijá (Godoi et al., 2001). Lacerda
Filho et al. (2006) denominaram-na de Suíte Amonguijá, subdividida em Granito Alumiador e Vulcânicas Serra da Bocaina, constituindo nas rochas magmáticas do Arco Magmático Amonguijá.

As rochas da Suíte Plutônica Alumiador afloram no Batólito Alumiador (Godoy et al., 2006, 2009a, 2014; Manzano et al., 2012) e são compostas de rochas isotrópicas a fracamente anisotrópicas, leucocráticas, de coloração cinza a rósea, cálcio-alcalinas de alto potássio a shoshonítica, peraluminosas a metaluminosas e correlacionadas a ambientes sin-colisionais de arco magmático a pós-colisionais intraplaca.

Lacerda Filho et al. (2006) e Silva et al. (2007) apresentaram para as fácies plutônicas idade U-Pb em zircão de $1,86 \mathrm{Ga}$, idade modelo $\mathrm{T}_{\mathrm{DM}} 2,17 \mathrm{Ga}$ e valores de $\varepsilon \mathrm{Nd}^{(t)}$ negativos (0.68), que apontam para um arco juvenil de margem continental com pouca participação de material crustal. Cordani et al. (2010) apresentaram resultados idade U-Pb de $1,84 \mathrm{Ga}$, idades modelo $\mathrm{T}_{\mathrm{DM}}$ de $2,50 \mathrm{Ga}$ e valores de $\varepsilon \mathrm{Nd}^{(t)}$ negativos $(-2,86$ a $-5,91)$, sugerindo uma assinatura isotópica para os protólitos intrusivos com forte participação de material crustal.

Silva (1998) descreveu a Serra da Alegria como intrusão diferenciada gabro-anortosito-granofírica da Serra da Alegria, petrograficamente distinta dos demais segmentos por apresentar granitos, granófiros, gabros, anortositos e ultrabásicas, caracterizando uma série magmática com estruturas típicas de complexos estratiformes. Godoy et al. $(2009 \mathrm{~b}, 2010,2014)$ propuseram a esse segmento do Batólito Alumiador a designação de Magmatismo ÁcidoIntermediário da Serra da Alegria; o conjunto de rochas de composição intermediária-ácida foi denominado de Granito Serra da Alegria; e o conjunto de rochas básicas-ultrabásicas foi nomeado de Magmatismo Gabro-Anortosítico da Serra da Alegria.

Faleiros et al. (2015) denominaram as rochas ácidas da Serra da Alegria de Granito Santa Otília e apresentam idade U-Pb (SHRIMP) em zircão de 1,83 + 12 Ga. Nogueira et al. (2013) denominaram essas mesmas rochas ácidas de "Granito Aquidabã" e obtiveram idade U Pb (SHRIMP) em zircão de $1,81 \pm 6,8 \mathrm{Ga}$, valores $\varepsilon N d$ negativos $(-2,18$; $-4,37 ;-1,50)$ e idades modelo $\mathrm{T}_{\mathrm{DM}}$ de $2,35 \mathrm{Ga}, 2,57 \mathrm{Ga}$ e $2,26 \mathrm{Ga}$.

Lacerda Filho et al. (2006) e Silva et al. (2008) denominaram o conjunto de rochas básicas de Intrusão GabroAnortosítica Serra da Alegria e as separaram do Batólito Alumiador. Apresentaram, para o anortosito, idade U-Pb (SHRIMP) em zircão de $1,79 \mathrm{Ga}$, idade modelo $\mathrm{T}_{\mathrm{DM}}$ de $2,51 \mathrm{Ga}$ e valores de $\varepsilon \mathrm{Nd}_{(\mathrm{t})}$ negativos $(-2,89 \mathrm{a}-4,32)$, sugestivos de forte contaminação crustal. Cordani et al. (2010) apresentam, para o anortosito, idade U-Pb (SHRIMP) em zircão de $1,8 \mathrm{Ga}$, idade modelo $\mathrm{T}_{\mathrm{DM}}$ de $(2,50$ a $2,64 \mathrm{Ga}) \mathrm{e}$ valores de $\varepsilon \mathrm{Nd}^{(t)}$ negativos $(-3,21$ a $-4,31)$. 


\section{GEOLOGIA LOCAL}

O Batólito Alumiador é caracterizado como um corpo alongado segundo a direção geral N-S, com exposição da ordem de $180 \mathrm{~km}^{2}$, que se encontra seccionado por falhamentos transcorrentes com direção NW-SE, intrusivo em rochas encaixantes do Complexo Rio Apa, do Grupo Alto do Tererê e, raramente, com subvulcânicas da Serra da Bocaina (Godoy et al., 2014). O mapa geológico apresenta as distribuições das unidades litológicas da área do Batólito Alumiador e, especificamente, da Serra da Alegria (Figuras 1A e 1B).

$\mathrm{O}$ quadro estrutural-metamórfico identificado nas unidades litológicas do Maciço Rio Apa encontra-se definido por cinco fases deformacionais, sendo as duas iniciais atribuídas a eventos paleo a mesoproterozoicos, com paragêneses metamórficas em fácies anfibolito, e as demais pelo arranjo tectônico-metamórfico superimposto da Faixa de Dobramentos Paraguai, de idade neoproterozoica, impondo paragêneses metamórficas hidratadas em fácies xisto verde (Godoy et al., 2009a).

Os litotipos do Complexo Rio Apa são a unidade mais antiga na área e são caracterizados por hornblenda-biotita gnaisse, gnaisse migmatítico e migmatito ortoderivado, além de raro anfibolito e metagranitoide. O Grupo Alto Tererê ocorre em exposições na forma de pequenas elevações que se destacam na paisagem nas áreas inundáveis da Planície Pantaneira. Essa unidade metavulcanossedimentar é composta por granada micaxisto, quartzito micáceo, raramente por biotita gnaisse fino e, em menores proporções, por anfibolito, anfibólio xisto e clorita xisto.

As rochas do Complexo Amonguijá caracterizadas na área são constituídas pelas suítes ácidas-intermediárias, anteriormente definidas por Godoi et al. (2001) de Plutônica Alumiador e Vulcânica Serra da Bocaina.

A suíte vulcânica na área aflora na forma de ocorrências menos expressivas constituídas por uma diversidade textural de rochas subvulcânicas (riolito e microgranito), vulcânicas (riolito porfirítico e fluxos de lava) e vulcanoclásticas.

A Serra da Alegria constitui a principal elevação exposta e orientada segundo a direção NW, destacando-se entre os sedimentos quaternários da Bacia do Pantanal, como observado na Figura 2A. Sua ocorrência é marcada no contato oeste por um relevo escarpado, definido pelos contrafortes erosivos da serra, consequente reativação em ambiente extensionais dos falhamentos profundos de direção NW. Já o contato leste encontra-se com relevo menos íngreme e parcialmente recoberto pelos sedimentos da Bacia do Pantanal, que gradam em direção da serrania principal.

Devido à segmentação espacial do Batólito Alumiador e à ausência de correlações de campo entre os segmentos, a parte norte, denominada de Serra da Alegria, apresenta-se, quanto à composição, à textura e aos aspectos evolutivos, distinta e com uma evolução independente aos demais segmentos da Suíte Plutônica Alumiador, mas constituindo um evento magmático contemporâneo aos demais segmentos (Godoy et al., 2006, 2009a, 2009b, 2010).

A evolução do segmento magmático da Serra da Alegria é considerada como sequências diferenciadas e contemporâneas: uma intermediária-ácida, que domina a área central da serra, e a outra de composição básica-ultrabásica, que ocorre nas regiões marginais do conjunto principal, ambas envolvidas em processos de misturas magmáticas e contaminações crustais (Godoy et al., 2014).

As rochas que compõem o Magmatismo ÁcidoIntermediário da Serra da Alegria ocorrem principalmente sob a forma de blocos e matacões, e afloram em todo o contato leste da serra, nas partes elevadas do contato oeste e nas altitudes mais elevadas e de relevo intensamente acidentado. Essas condições dificultam a circulação na parte central da serrania e na mata nativa preservada dos retiros das Fazendas Regina e Santa Otília.

$\mathrm{Na}$ área central dominam os diferenciados intermediários-ácidos granofíricos que são constituídos por sieno- a monzogranito, vermelho, hololeucocrático, equi a inequigranular de granulações fina a média, localmente microporfirítico, granofírico e isotrópico (Figura 2B). Em menores proporções ocorrem rochas de composição intermediária, que são constituídas por quartzo monzonito, quartzo sienito e quartzo monzodiorito de coloração vermelha. Essas variedades litológicas de composições intermediárias também estão preservadas na forma de enclaves de composição quartzo monzodiorítica no conjunto ácido.

O conjunto central desse magmatismo apresenta características texturais de rochas subvulcânicas ácidas e básicas, $\mathrm{o}$ que corrobora que foram formadas em episódios magmáticos de uma fase final do magmatismo do Batólito Alumiador, instalando-se em níveis crustais mais rasos e em condições de maior estabilidade (Godoy et al., 2014).

Na parte central do corpo, o conjunto magmático predominante, de composição intermediária-ácida, é intrudido por várias intrusões circulares menores, de composição ácida, constituídas de microgranito e atribuídas a episódios magmáticos sincrônicos e repetitivos, na acresção da área do batólito. Parte dessas intrusões encontra-se, em menores proporções, parcialmente circundada por rochas subvulcânicas básicas na forma de pequenos corpos de diabásio, na base dos corpos mais elevados de composição ácida (Figura 1B).

Nessas intrusões circulares é comum a ocorrência de diabásio mesocrático, de cor cinza a negra, de textura maciça, equigranular e granulação fina a média (Figura 2C). Ocorrem, às vezes, feições porfiríticas e a presença de diversos subtipos de leuco diabásio equigranulares a porfiríticos (Figura 2D). Associados a esse conjunto básico, encontram-se fácies aplíticas, veios residuais finos e pegmatíticas de composição básica a ácida, resultantes da intensidade no processo de diferenciação magmática. 

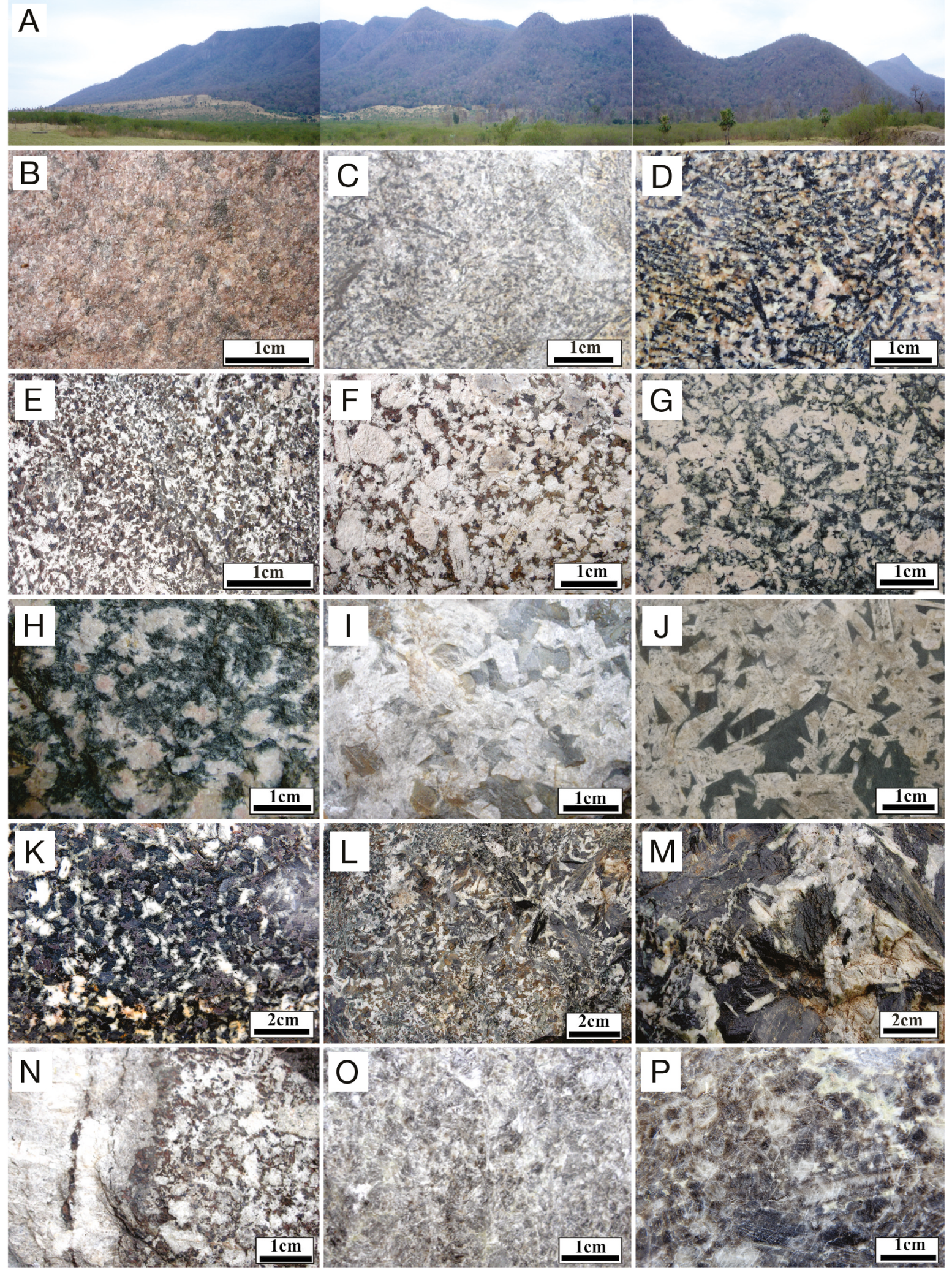

Figura 2. Fotografias de aspectos geomorfológicos da serra e dos principais tipos petrográficos do Magmatismo GabroAnortosítico da Serra da Alegria. (A) Destaque geomorfológico da Serra da Alegria; (B) sieno a monzogranito vermelho; (C) leuco diabásio; (D) diabásio grosso; (E) magnetita gabro; (F e G) leuco gabro porfirítico; (H) mela gabro grosso; (l e J) leuco gabro pegmatítico; (K, L e M) mela gabro pegmatítico; (N) contato entre o magnetita gabro e anortosito; $(\mathrm{O}$ e $\mathrm{P})$ anortosito. 
As rochas que compõem o Magmatismo GabroAnortosítico da Serra da Alegria são definidas pelas intrusões plutônicas de rochas diferenciadas cumuláticas de composição básicas-ultrabásicas, que ocorrem principalmente dispostas lateralmente ao conjunto ácido, nos contatos oeste e sul. Ocupam as áreas marginais externas e sopés da serra, na forma de extensos afloramentos, caracterizados por paredões e grandes matacões de rochas da sequência diferenciada, associadas a corpos e blocos rolados menores de rochas graníticas, que apresentam feições texturais microporfiríticas a faneríticas finas das partes mais íngremes da serra.

A parte exposta da intrusão gabro-anortosítica é constituída dominantemente por gabro menos diferenciado (Figuras 2E a 2G), que grada em direção às partes basais, por segregações dos minerais máficos, para rochas melanocráticas a ultramelanocráticas: o melagabro (Figura $2 \mathrm{H}$ ) e raro piroxenito. Transicionam para as partes superiores da intrusão, por flotação de plagioclásio, para tipos leucocráticos, como o leuco gabro de granulação variável (Figuras 2I e 2J), quartzo gabro e anortosito. Localmente, encontram-se preservadas rochas gabroides variando, para a base, para litotipos melanocráticos de granulação grossa ou mesmo para bolsões de mela pegmatito básico, contemporâneos e de granulometria diversas (Figuras $2 \mathrm{~K}$ a $2 \mathrm{M}$ ).

Os contatos entre os diferentes litotipos ocorrem de forma abrupta e contínua ou transicional (Figura 2N). Para o topo da sequência, mais diferenciada, é mais frequente a ocorrência de pegmatito básico. Veios enriquecidos, principalmente em plagioclásio, são comuns, além de ocorrerem localmente veios aplíticos de composição quartzo-feldspática.

$\mathrm{O}$ anortosito domina na parte mais elevada da serra, apresentando-se isotrópico, leucocrático e de cor branca a cinza, homogêneo e equigranular de granulações média a grossa (Figuras $2 \mathrm{O}$ e 2P), mas também pode ser heterogêneo e inequigranular a pegmatoide, além de bandado ou acamadado. Quando presentes o acamamento e o bandamento magmático, essas feições são definidas por concentrações de minerais opacos e máficos.

Interpretações

A sequência gabro-anortosítica da Serra da Alegria é interpretada como colocada em ambientes extensionais e provém inicialmente de um corpo magmático máfico-ultramáfico parental enriquecido em ferro e titânio, gerado em níveis crustais relativamente profundos. A partir de processos de fracionamento do magma, resultou em magmas residuais diferenciados, segregados e enriquecidos em óxidos de Fe e Ti, que se posicionaram por meio de falhamento em níveis mais rasos da crosta.

A partir de processos magmáticos de cristalização fracionada, segregação de líquidos residuais magmáticos enriquecidos em ferro e segregação gravítica de um magma silicático, há flutuação do plagioclásio e acúmulo na parte superior da câmara magmática, com formação dos anortositos e segregação de cumulatos de ferro nas partes inferiores, podendo gerar um magma denso e muito rico em ferro, o que levaria a uma tendência do mineral de ferro de se acumular sob a forma de camadas no fundo da câmara magmática.

As acumulações de magnetita localizadas podem estar presentes como corpos maciços, definindo pequenos bandamentos ou extratos, ou ocorrer disseminadas em rochas silicáticas homogêneas e em veios, lentes ou camadas de óxido de ferro, constituindo contatos bruscos com as rochas hospedeiras. Esse processo magmático de cristalização fracionada permitiu a geração de grande variedade de litotipos magmáticos.

\section{PETROGRAFIA}

O conjunto de rochas de composição gabro-anortosítica da Serra da Alegria apresenta paragêneses ígneas anidras de altas temperaturas que são constituídas por clinopiroxênio e labradorita. Observam-se nessas rochas uma fraca anisotropia e paragêneses regionais metamórficas hidratadas superimpostas, além da manutenção de pseudomorfos ígneos e texturas magmáticas primárias que podem incluir cumulato, bem como texturas ofítica e subofítica, equigranulares a inequigranulares. A mineralogia reflete a desestabilização mineral por hidratação, em condições metamórficas mais brandas, associadas ao metamorfismo regional final superimposto em fácies xisto verde, de idade neoproterozoica e a consequente geração de paragêneses metaígneas estáveis a partir de minerais de alterações, formados por processos de uralitização, sericitização, saussuritização e cloritização. Frequentemente, as transformações em minerais hidratados são totais, mas podem-se preservar pseudomorfos, principalmente de piroxênio. Quando parcialmente substituídos, nos piroxênios observam-se as suas bordas substituídas por actinolita/tremolita e clorita, e nas bordas dos cristais de plagioclásio, observam-se processos de recristalização para albita e internamente texturas secundárias de saussuritização.

Os principais minerais nessas rochas referem-se a cristais de clinopiroxênio (augita e ferro augita) e plagioclásio (andesina/labradorita), raramente e em proporções pequenas, quartzo e feldspato potássio, além dos minerais acessórios rutilo, zircão, titanita, apatita e sulfeto, tais como calcopirita e pirrotita, que podem ocorrer inclusos nos grãos de óxidos de ferro, em fraturas e individualizados, além de minerais secundários, como actinolita/tremolita, clorita, epidoto, sericita, calcita, leucoxênio e albita.

Algumas variedades de rochas gabroides, da parte basal da sequência, apresentam-se mais enriquecidas em magnetita, constituindo feições de lentes e acamamento ou bandamento irregulares, podendo atingir, localmente, porcentagens acima de $20 \%$ de magnetita, com granulometria muito grossa e megacristais observáveis a olho nu (Figura 3A). 

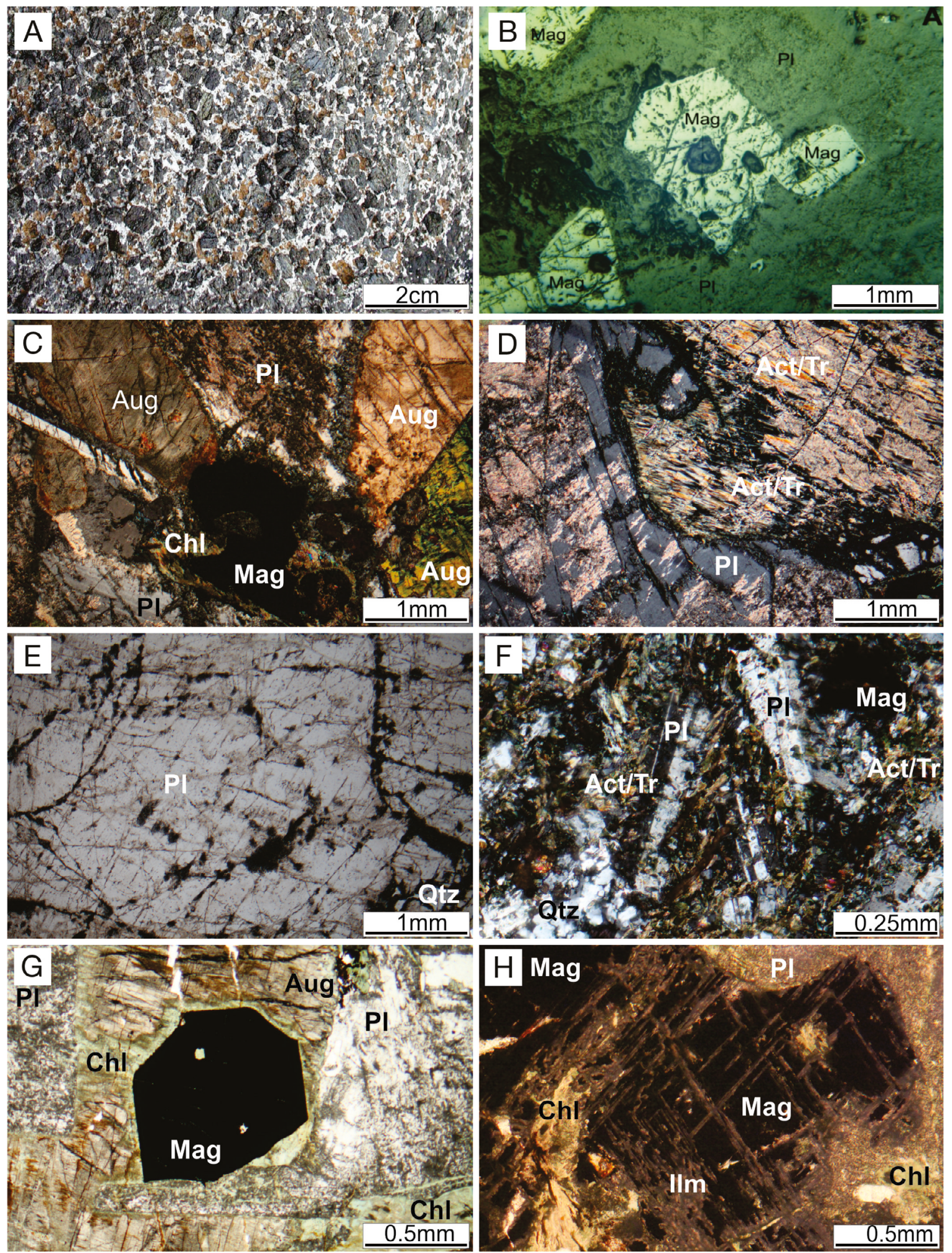

IIm: IImenita; Chl: clorita; Aug: augita; Mag: magnetita; PI: plagioclásio; Act/Tr: actinolita/tremolita; Qtz: quartzo.

Figura 3. (A) Amostra macroscópica de magnetita-augita gabro. (B) Fotomicrografia de magnetita euhedrais em seção polida de magnetita gabro. Fotomicrografias de seções delgadas com polarizadores cruzados da mineralogia dos principais tipos petrográficos. (C) labradorita e augita em gabro; (D) piroxênio uralitizado e plagioclásio sericitizado em gabro; (E) plagioclásio em anortosito; (F) plagioclásio e actinolita/tremolita em diabásio; (G) magnetita euedral em magnetita gabro; $(\mathrm{H})$ magnetita com exsoluções de ilmenita. 
Na Figura 3B são apresentados cristais de magnetita euhedrais vistos em microscópio de luz transmitida.

Os conjuntos de gabro (Figura 3C) apresentam grande variação nas porcentagens dos seus minerais. São constituídos por clinopiroxênio (augita), além de pseudomorfos parcial a totalmente uralitizados, que originam hornblenda e evoluem para agregados de filossilicatos microcristalinos verdes (biotita, clorita e actinolita) (Figura 3D), plagioclásio (andesina/labradorita) (Figura 3E), que comumente apresenta forte alteração para filossilicatos incolores (sericita) e a formação de albita metamórfica, raros grãos de quartzo intersticiais e feldspato alcalino, com porções intersticiais mais félsicas apresentando textura microgranofírica constituída por quartzo e feldspato alcalino (pertítico). Os minerais acessórios são constituídos por apatita, titanita, rutilo e zircão. Os minerais opacos são representados principalmente por magnetita primárias distribuídas sob a forma de cristais anedrais a subedrais representados por óxidos de $\mathrm{Fe}$ e Ti, além de ilmenita, associados à presença de sulfetos, como pirita e calcopirita. Os minerais secundários são hornblenda, calcita, epidoto, clinozoisita, biotita, sericita, clorita e actinolita/tremolita (Figura 3F).

O anortosito é isotrópico, leucocrático e de cor branca a cinza. Essa unidade apresenta-se recortada por veios de espessura milimétrica de quartzo, epidoto e clorita de cor esbranquiçada em fraturas de várias direções. A mineralogia principal é constituída de andesina/labradorita (>90\%) intensamente alterada para filossilicatos incolores (sericita), epidoto, clinozoisita, além de raros pseudomorfos de clinopiroxênio associados à massa de agregados de actinolita, carbonato, clorita e minerais opacos. São frequentes também como minerais secundários sericita e clorita. Os minerais acessórios presentes são apatita, titanita, zircão, rutilo, magnetita, sulfetos e minerais opacos indistintos.

O diabásio a leuco diabásio apresenta texturas equigranular e inequigranular a microporfirítico (Figura 3G) e é constituído de plagioclásio (labradorita-andesina) e clinopiroxênio (augita) na forma de cristais euédricos a subédricos, tabulares, e menos frequentemente, fenocristais de até $1 \mathrm{~cm}$ de comprimento. A matriz é composta por plagioclásio, piroxênio, feldspato potássico e quartzo.

Os diabásios apresentam texturas ofítica e subofítica e são constituídos de $\pm 65 \%$ de plagioclásio, $\pm 15 \%$ de clinopiroxênio (augita), $\pm 10 \%$ de hornblenda, $\pm 6 \%$ de minerais opacos, $\pm 2 \%$ de clorita, $\pm 1 \%$ de apatita, $\pm 1 \%$ de biotita. Os minerais acessórios são representados por zircão, titanita, magnetita, ilmenita e pirita. Os minerais secundários são constituídos por processos de uralitização do clinopiroxênio que, no geral, ocorrem alterando a borda dos cristais maiores para anfibólio (hornblenda e actnolita). Geralmente juntos e associados a esses cristais observam-se agregados constituídos por minerais opacos irregulares e esqueletais, biotita com aspecto fibroso, filossilicatos verdes (clorita) e calcita; verificam-se também, a partir da saussuritização do plagioclásio, transformações para epidoto (clinozoizita) e sericita.

Os cristais de magnetita, quando em elevadas concentrações, geram corpos acamados concordantes a raros levemente discordantes com as rochas. A magnetita é bem formada, euhedral, e apresenta contatos retos a levemente curvilíneos com os outros cristais, disseminadas e intersticiais (Figura 3F); quando se encontra parcialmente fraturada, ocorre uma acentuada transformação para hidróxido de ferro. $\mathrm{Na}$ Figura 3G, observam-se lamelas exsolvidas de ilmenita.

A magnetita exibe várias texturas de exsolução de ilmenita. Como produto de cristalização direta ocorre o intercrescimento de cristais de ilmenita exsolvidos em magnetita, gerando lamelas de titanomagnetita e ulvoespinélio como exsolução na magnetita. Por oxi-exsolução origina-se durante o resfriamento, a fase de intercrescimento de ulvoespinélio, ocorrendo na forma de segregação nos planos octaedrais da magnetita. E, por decréscimo da temperatura, há a oxidação (processo oxi-exsolução) do componente ulvoespinélio, transformando-o em ilmenita. As exsoluções ocorrem em grãos de exsolução interna, ao longo de planos de clivagem, na forma de treliça, lamelar e manchas irregulares e disformes, intercrescendo no interior da magnetita, além de exsolução interna e externa, que corresponde aos cristais de ilmenita em contato direto com a magnetita.

\section{QUÍMICA MINERAL}

O estudo de química mineral da sequência gabro-anortosítica da Serra da Alegria foi desenvolvido nos principais minerais formadores da paragênese ígnea. A sequência diferenciada cumulática observada é composta basicamente por gabro, anortosito e raras camadas de piroxenito cumulático. Essa diferenciação possibilita a formação de um depósito magmático cumulado básico estratiforme semiconcordante, possibilitando, nas partes basais, a formação de camadas de magnetitito, na forma de cumulus de óxidos de ferro: em magnetita, Fe-magnetita $\left[\left(\mathrm{Fe}^{+2} \mathrm{Fe}^{+3}\right) \mathrm{O}_{4}\right]$ e em titânio, Ti-magnetita $\left[\left(\mathrm{Fe}^{+2} \mathrm{Fe}^{+3} \mathrm{Ti}\right) \mathrm{O}_{4}\right]$ (titanomagnetita - ulvoespinélio), constituindo os minerais de cúmulos predominantes. Associados a quantidades menores de vanádio, $\mathrm{V}$ - magnetita $\left[\left(\mathrm{Fe}^{+2} \mathrm{~V}^{+3}\right) \mathrm{O}_{4}\right]$, de ilmenita $\left[\mathrm{Fe}^{+2} \mathrm{TiO}_{3}\right]$ e de $\mathrm{Fe}$ - ilmenita que constitui a fase subordinada. Os minerais analisados a partir da microssonda eletrônica foram piroxênio, plagioclásio e óxido de ferro-titânio. Não foi observada martitização (oxidação) de magnetita $\left(\mathrm{Fe}_{3} \mathrm{O}_{4}\right)$.

\section{Plagioclásio}

$\mathrm{Na}$ Figura 4A, de imagem de microscópio eletrônico de varredura (elétrons retroespalhados) de gabro da Sequência 
Magmática Gabro-Anortosítica da Serra da Alegria, são observados cristais de plagioclásio (Figura 4B), que apresentam variações composicionais com respeito ao teor de anortita entre $\mathrm{An}_{36,76}-\mathrm{An}_{58,06}$ (Tabela 1), predominando composições entre andesina e labradorita (Figura 5, Tabela 1). Os cristais não exibem zoneamento químico, apenas porções de composições diferentes internamente e, em sua vasta maioria, correspondem a andesina e a labradorita.

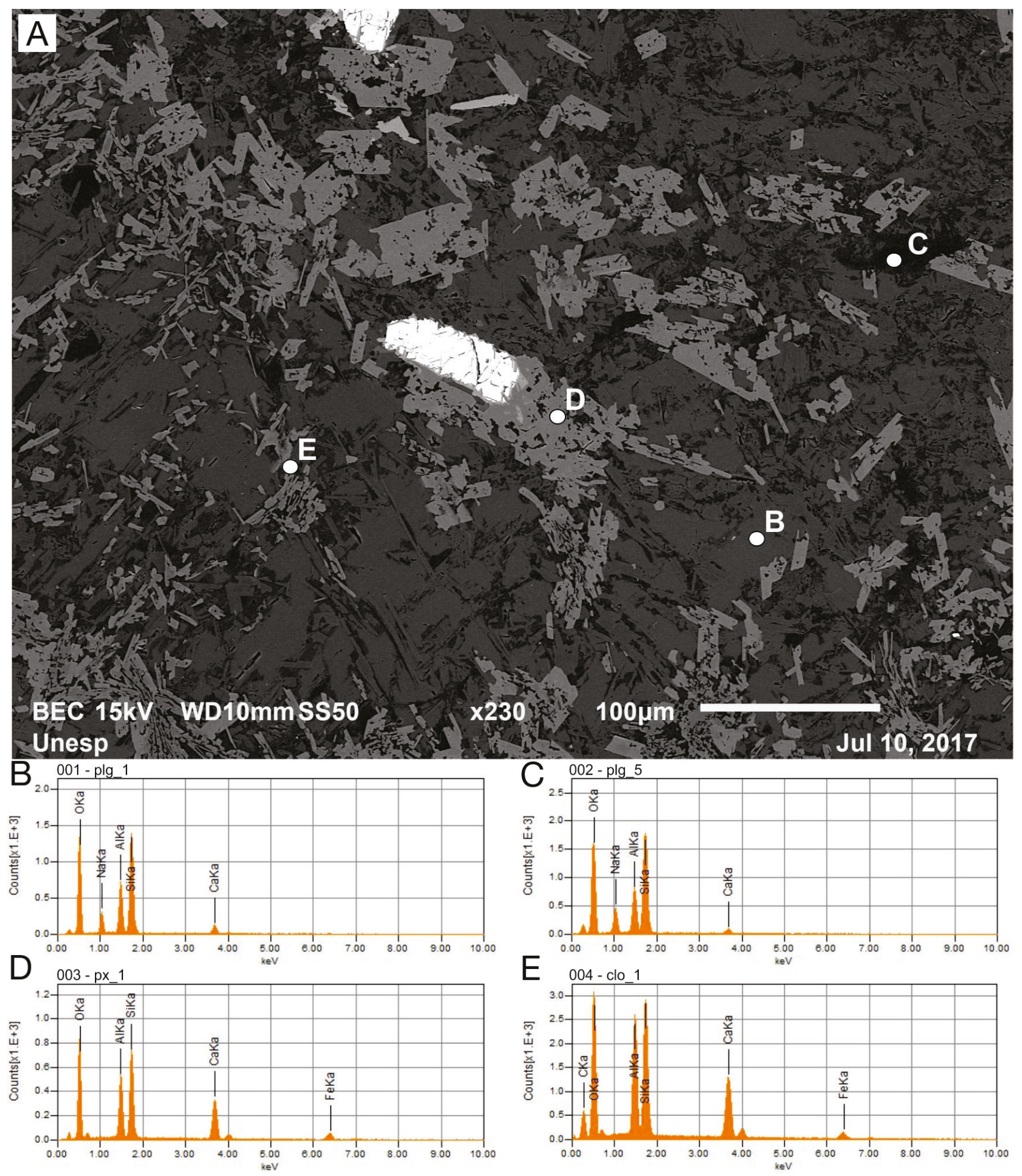

Figuras 4. (A) Imagem de microscópio eletrônico de varredura (elétrons retroespalhados), em gabro da Sequência Magmática Gabro-Anortosítica da Serra da Alegria. Análise qualitativa de cristais: (B) andesina; (C) albita; (D) augita; (E) clorita. 
Os cristais de albita referem-se a minerais secundários do estágio metamórfico.

A albita, identificada na Figura 4C, ocorre nas bordas de alguns grãos de cristais primários de andesina/labradorita e raramente constitui pequenos grãos dispersos na matriz, sendo fortemente identificada e associada conjuntamente a pseudomorfos de augita (Figura 4D), além de serem observadas clorita secundárias (Figura 4E).

\section{Piroxênio}

Os cristais de piroxênio (Figura 4D) analisados conforme mostrado na Figura 4A foram classificados (Figura 6) com base na proporção dos membros finais ou das moléculas de diopsídio $\left(\mathrm{CaMgSi}_{2} \mathrm{O}_{6}\right)$, hedenbergita $\left(\mathrm{CaFeSi}_{2} \mathrm{O}_{6}\right)$, enstatita $\left(\mathrm{MgSiO}_{3}\right)$ e ferrosalita $\left(\mathrm{FeSiO}_{3}\right)$, segundo a proposta de Morimoto (1990).

Das dez amostras de piroxênio, três são clinopiroxênio cálcico do tipo augita e sete são clinopiroxênio cálcico do tipo ferro-augita (Tabela 2). Os cristais encontram-se parcialmente uralitizados, o que explica o fechamento pontual dos óxidos total abaixo do esperado ( $\sim 96 \%)$.

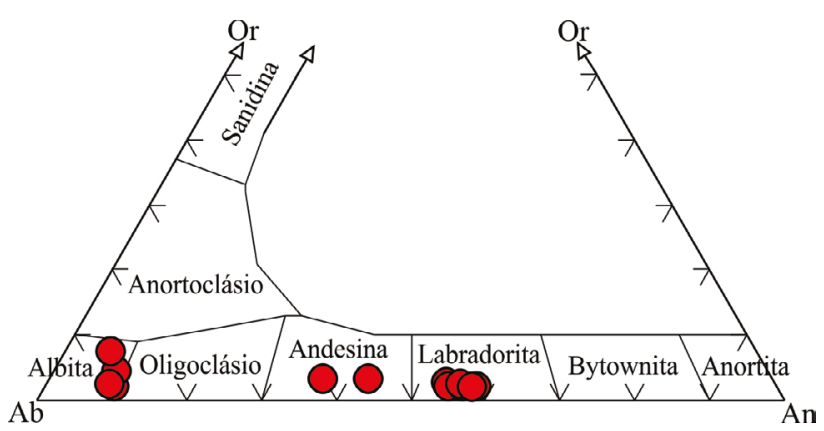

Figura 5. Diagrama de composição de plagioclásio em gabro da Sequência Magmática Gabro-Anortosítica da Serra da Alegria, a partir de valores de K (Or - ortoclásio), $\mathrm{Na}(\mathrm{Ab}$ - albita), $\mathrm{Ca}(\mathrm{Na}$ - anortita).

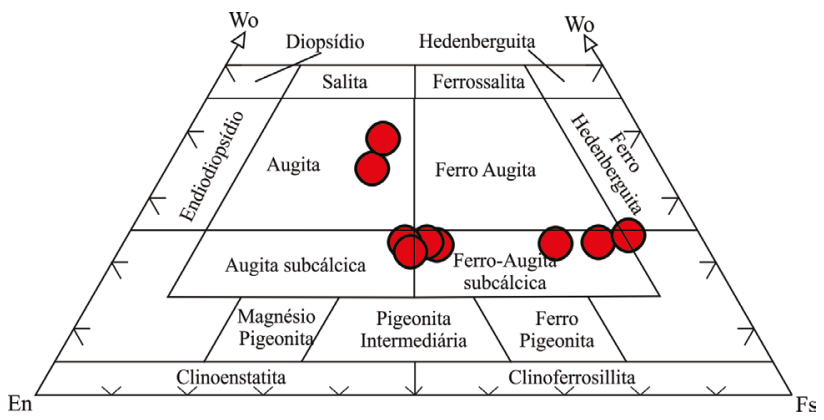

Figura 6. Diagrama no sistema $\mathrm{MgO}-\mathrm{FeO}-\mathrm{CaO}$ aplicado na classificação e nomenclatura dos piroxênios de rochas da Sequência Magmática Gabro-Anortosítica da Serra da Alegria. Legenda: Ca (Wo - wollastonita), Mg (En enstatita) e Fe (Fs - ferrosalita).

\section{Óxido de ferro}

As análises em MEV-EDS (Figura 7A) e microssonda indicam que o mineral ferromagnético presente (Figura 7B) corresponde a titanomagnetita (ulvoespinélio) (Figura 7C), ilmenita (Figura 7D) e principalmente magnetita (Figura 7E). Na Figura 8 é apresentado o diagrama de classificação de minerais do grupo do espinélio, baseado nas análises da Tabela 3 .

A magnetita é representante de uma solução sólida de óxidos de ferro $\left(\mathrm{FeO} \mathrm{Fe}_{2} \mathrm{O}_{3}\right.$ ), apresentando $69 \% \mathrm{FeO} .31 \% \mathrm{Fe}^{2} \mathrm{O}^{3}$ ou $72,4 \% \mathrm{Fe} .26,7 \% \mathrm{O}$, e ocorre constituindo cristais de cumulus na forma de grãos com a ilmenita, formando uma trama granular poligonal e na forma tipicamente euédrica dos grãos de granulação variável. A granulação fina a média, associada às rochas mais ricas em minerais silicáticos e, a granulação mais grossa dos grãos de óxidos associados às rochas mais enriquecidas em magnetita, os magnetititos.

Os grãos de magnetita contêm, internamente, sob a forma de lamelas, filetes, inclusões e exsoluções de ilmenita e titanomagnetita.

No total, 14 cristais de óxidos foram analisados e os resultados são apresentados na Tabela 3. Para a magnetita, os valores de $\mathrm{FeO}^{t}$ variaram entre 88,03 e 92,98\%; $\mathrm{de}^{\mathrm{TiO}_{2}}$ entre 1,13 e $6,39 \%$ e de $\mathrm{V}_{2} \mathrm{O}_{5}$ entre 0,75 e $0,98 \%$.

A ilmenita é representante de uma solução sólida de óxidos de ferro-titânio $\left(\mathrm{FeO} \cdot \mathrm{TiO}_{2}\right)$ e apresenta composição de aproximadamente $36,8 \% \mathrm{Fe} .31,6 \% \mathrm{Ti} .31,6 \% \mathrm{O}$. Ocorre como grãos euédricos ou exsolvida de maneira disforme na magnetita, ou ao longo de planos de clivagem constituindo lamelas e filetes geralmente retos.

A ilmenita lamelar observada é caracterizada por formar um conjunto paralelo de lamelas bem definidas nos grãos hospedeiros de magnetita. Filetes de ilmenita, entrelaçados em ângulo agudo, também ocorrem nos grãos de magnetita, definindo um arranjo de treliça e que é interpretado como processo de oxi-exsolução da ilmenita nos planos de clivagem da magnetita homogênea. Nessas rochas a ilmenita apresenta-se como exsoluções e inclusões na magnetita e tem conteúdo entre 45,83 e 50,87\% de $\mathrm{FeO}^{\mathrm{t}}$ e entre 43,95 e 53,10\% de $\mathrm{TiO}_{2}$.

A titanomagnetita constitui-se em uma solução sólida de óxidos de ferro-titânio $\left(\mathrm{Fe}_{2} \mathrm{TiO}_{4}\right),\left(70 \% \mathrm{Fe}_{3} \mathrm{O}_{4} \cdot 30 \% \mathrm{TiO}_{2}\right)$, formada pela solução sólida de magnetita $\left(\mathrm{Fe}_{3} \mathrm{O}_{4}\right)$ e ulvoespinélio $\left(\mathrm{Fe}_{2} \mathrm{TiO} 4\right)$ e ocorre sob a forma de lamelas de exsolução finas e descontínuas, superpostas aos planos de clivagem da magnetita (Figura 7A). Apresenta entre 75,82 e 83,22\% de FeOt,

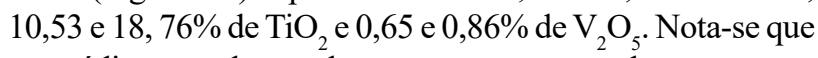
o vanádio tem valores relevantes em ppm quando com a magnetita (4965-6027 ppm) e a titanomagnetita (3648-6310 ppm).

\section{Interpretações}

Os grãos de magnetita contêm, internamente, sob a forma de lamelas, filetes, inclusões e exsoluções de ilmenita e titanomagnetita. 
A presença marcante de magnetita como principal óxido de ferro indica condições de maior fugacidade em oxigênio ou o seu incremento, durante o processo de cristalização magmática, enquanto os valores cada vez mais baixos de fugacidade permitiriam, respectivamente, o surgimento Ti-magnetita (ulvoespinélio) e de ilmenita. Essa ilmenita, que se forma segregada

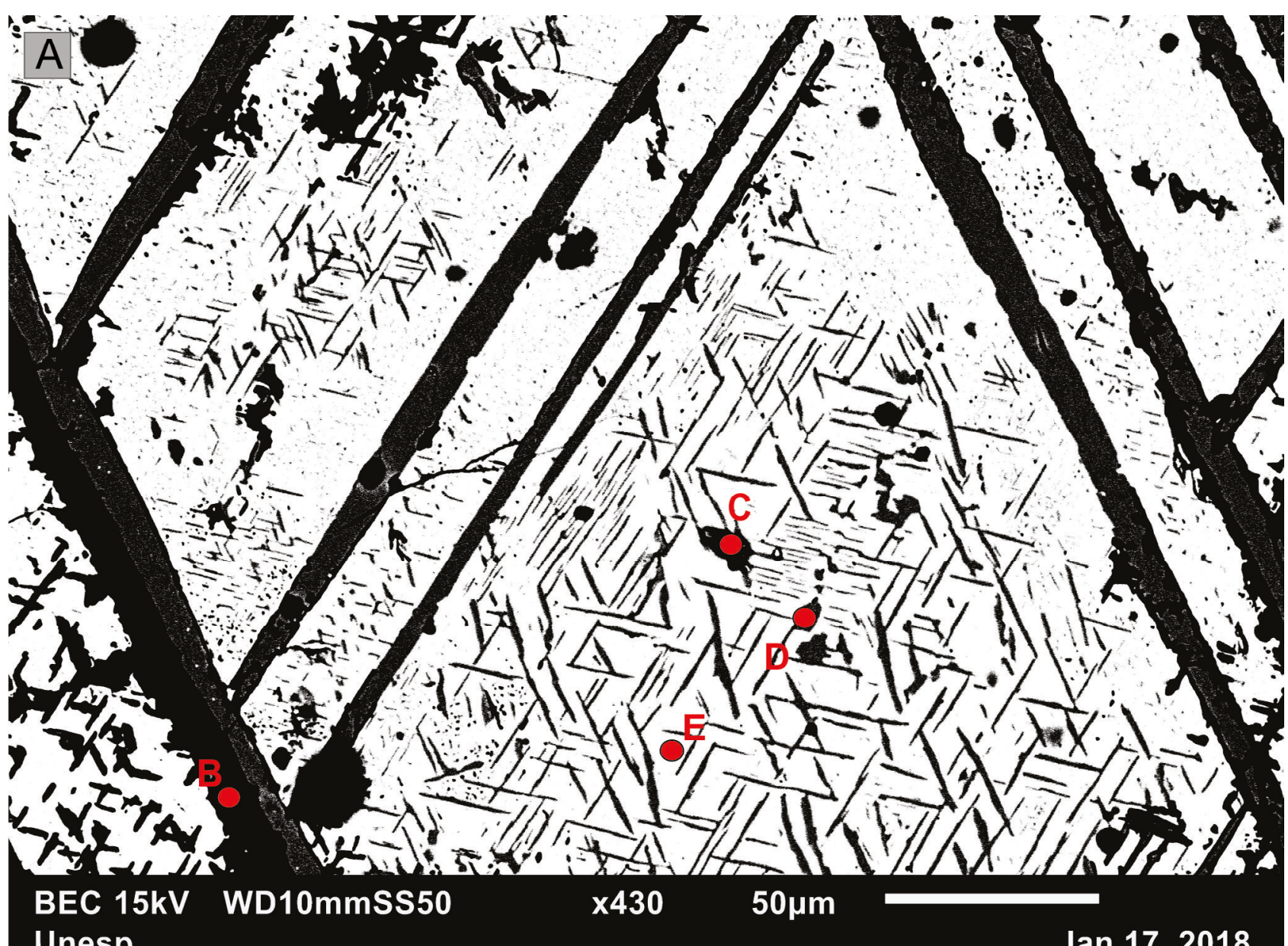

\section{Unesp}
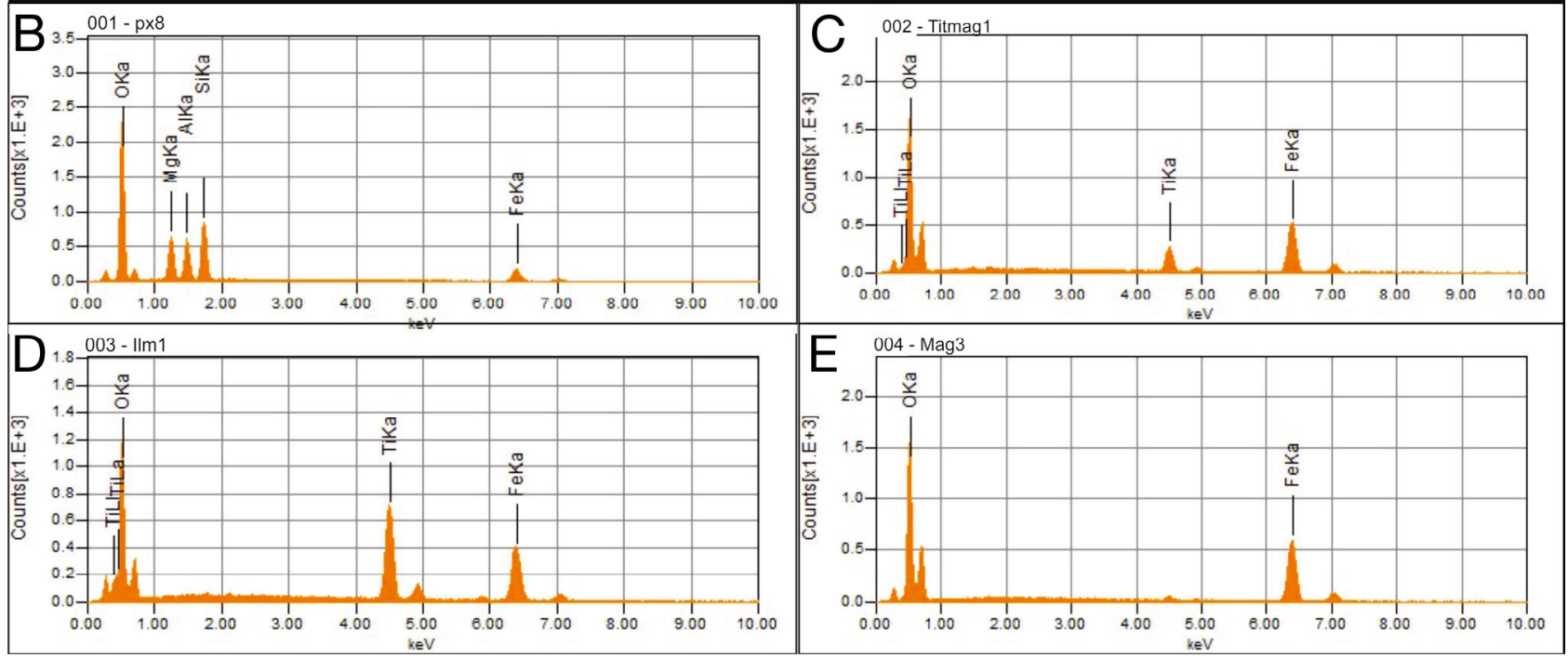

Figura 7. (A) Imagem de microscópio eletrônico de varredura (elétrons retroespalhados) de gabro. Análise qualitativa de cristais: (B) piroxênio; (C) titanomagnetita; (D) ilmenita; E) magnetita. Em gabro da Sequência Magmática GabroAnortosítica da Serra da Alegria. 
nos planos de clivagem da magnetita, é interpretada como o resultado do decréscimo da temperatura e, consequentemente, da intensificação do processo de oxidação (oxi-exsolução) do componente ulvoespinélio. Os óxidos de ferro e titânio em rochas magmáticas são fortemente dependentes das condições de oxidação durante o estágio magmático.

No total, 14 cristais de óxidos foram analisados e os resultados são apresentados na Tabela 3. Para a magnetita, os valores de $\mathrm{FeO}^{t}$ variaram entre 88,03 e 92,98\%; de $\mathrm{TiO}_{2}$ entre 1,13 e $6,39 \%$; e de $\mathrm{V}_{2} \mathrm{O}_{5}$ entre 0,75 e $0,98 \%$. As relações de substituição de ferro por titânio são vistas nas lâminas das ilmenita e na titanomagnetita. Quanto aos teores de cromo, vanádio e titânio, que ocorrem nas magnetitas substituindo o ferro, mostram teores de cromo muito baixos, visto que são depósitos cumuláticos altamente diferenciados a partir de rochas silicáticas e, portanto, o cromo, de raio iônico semelhante ao ferro e maior afinidade, já teria se exaurido em estágios iniciais de cristalização, na forma de cromita ou incorporado ao espinélio cromitífero e, consequentemente, nessa situação o vanádio $\mathrm{V}^{+3}$, de raio iônico maior e com menor afinidade, estaria concentrado e mais abundante no líquido residual, tendo nessa situação maior chance de preencher e substituir o ferro da magnetita ou titânio da ilmenita e da titanomagnetita. Consequentemente, o cromo estaria incorporado na magnetita em quantidades subordinadas.

\section{LITOQUÍMICA}

As análises de rocha total dos litotipos ultrabásicos-básicos da Serra da Alegria encontram-se enumeradas na

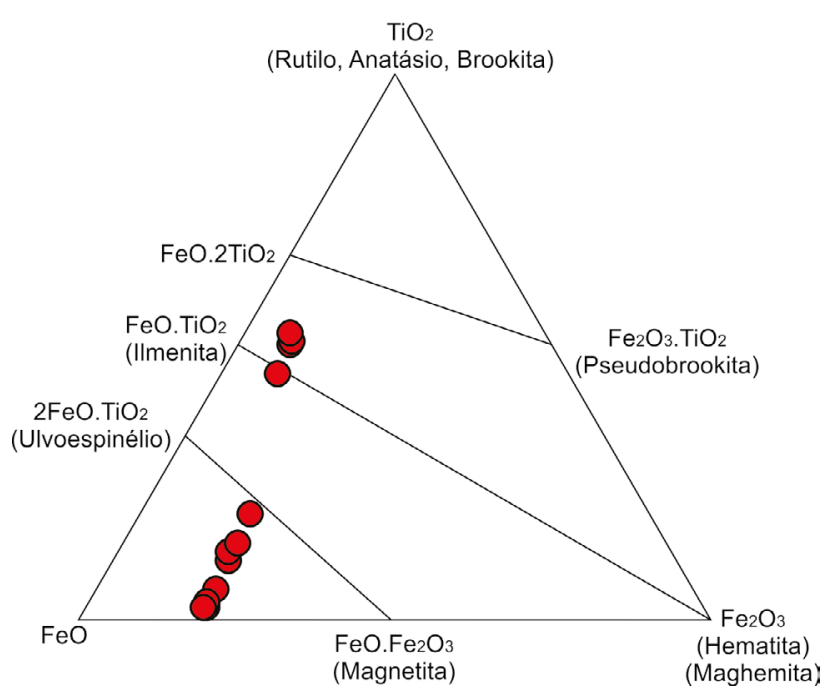

Figura 8. Diagrama de classificação para minerais do grupo do espinélio para amostras de rochas da Sequência Magmática Gabro-Anortosítica da Serra da Alegria, a partir de valores de $\mathrm{TiO}_{2}$, $\mathrm{FeO}$ e $\mathrm{Fe}_{2} \mathrm{O}_{3}$.
Tabela 4 e referem-se a dados descritos inicialmente em Godoy et al. (2014).

A partir dos dados químicos (Tabela 4) e de diagramas descritos em Godoy et al. (2014), a sequência de rochas básicas é composta de gabro, anortosito e diabásio, dispostas no intervalo 45 a $53 \% \mathrm{SiO}_{2}$, sendo possível individualizar duas unidades distintas. Uma unidade, em que a tendência de evolução é definida por gabros diferenciados para anortositos e pelos diabásios subalcalinos. Essa unidade é caracterizada pelas rochas básicas leucocráticas, constituídas por leuco gabros, podendo apresentar-se com granulações pegmatíticas, anortosito homogêneo e heterogêneo a bandado e o leuco diabásio alcalino que transaciona para composições tonalíticas a monzogábricas, apresentando geralmente teores mais elevados de $\mathrm{SiO}_{2}, \mathrm{Al}_{2} \mathrm{O}_{3}$ e $\mathrm{CaO}$ e teores mais baixos de $\mathrm{Fe}_{2} \mathrm{O}_{3}$ e $\mathrm{MgO}$.

A segunda unidade é definida por gabros e diabásios magnesianos constituídos por rochas básicas mesocráticas, compostas por gabro a mela gabro, mela gabro pegmatítico e diabásio toleítico, apresentando teores opostos para os dois conjuntos de elementos acima caracterizados.

No diagrama da Figura 9A (Winchester e Floyd, 1977), as amostras distribuem-se dominantemente entre o gabro e diabásio de composição subalcalina e o andesito, fora o anortosito, mais enriquecido em sílica e álcalis. No diagrama da Figura 9B (Jensen, 1976), as amostras das unidades são constituídas do gabro e dos diabásios, que apresentam composições Fe-toleíticas, e o anortosito, mais diferenciado, apresenta composições mais enriquecidas em alumínio, por causa da acumulação magmática de plagioclásio.

No diagrama da Figura 10A (Mullen, 1983), observa-se que as amostras de gabro e anortosito se distribuem principalmente no campo composicional do basalto toleítico de arco de ilha, enquanto o diabásio se apresenta com uma distribuição mais ampla, no campo composicional do basalto tolético de arco de ilha e/ou basalto de ilha oceânica. No diagrama da Figura 10B (Pearce e Norry, 1979), observa-se que as análises do gabro e diabásio se distribuem no campo do basalto toleítico intraplaca, enquanto as rochas anortosíticas estão posicionadas fora dos limites dos diagramas.

No diagrama de multielementos, os elementos incompatíveis para as rochas básicas-ultrabásicas estão normalizados segundo os valores de Weaver e Tarney (1984) para a crosta continental inferior (Figura 11A). Observa-se que os litotipos exibem empobrecimento em $\mathrm{Ba}, \mathrm{Nb}$ e Ti e enriquecimento em $\mathrm{Rb}, \mathrm{Sr}$ e $\mathrm{Zr}$, evidenciando processos de fracionamento envolvendo plagioclásio e minerais máficos. Para as rochas anortosíticas, os elementos-traço apresentam, no geral, valores empobrecidos, à exceção de Rb, Sr e Zr. Esses valores representam fortes anomalias positivas em função da acumulação de plagioclásio para as fases mais diferenciadas, 
sugerindo que esse processo magmático ocorre em câmera magmática e, geralmente, em níveis crustais rasos.

No diagrama de ETR para as rochas básicas-ultrabásicas, normalizadas segundo os valores de Boynton (1984), para meteoritos condríticos (Figura 11B), os valores de distribuição dos elementos para os gabros apresentam o comportamento dos elementos mais enriquecidos em $[\mathrm{La} / \mathrm{Yb}=$ $6,39]_{\mathrm{N}}$, leves anomalias de Eu, com $\left[\mathrm{Eu} / \mathrm{Eu}^{*}=0,10\right]_{\mathrm{N}}$, e um padrão simétrico, paralelo e sub-horizontal, definido pelo valor da relação $\mathrm{Ce} / \mathrm{Sm}=1,62$ e $\mathrm{Gd} / \mathrm{Yb}=2,18$. A exceção é somente para uma amostra de leuco gabro, que apresenta redução acentuada de ETR pesadas, reflexo da maior diminuição dos minerais ferromagnesianos.
As análises dos ETR para o anortosito evidenciam um padrão de distribuição total, com valores mais empobrecidos em $[\mathrm{La} / \mathrm{Yb}=10,45]_{\mathrm{N}}$, fortes anomalias positivas de $\mathrm{Eu}$, com $\left[\mathrm{Eu} / \mathrm{Eu}^{*}=0,66\right]_{\mathrm{N}}$, e um padrão assimétrico e paralelo definido pelo valor da relação $\mathrm{Ce} / \mathrm{Sm}=3,62$ e $\mathrm{Gd} / \mathrm{Yb}=$ 1,87. As anomalias positivas de Eu resultam da afinidade geoquímica do Eu com alumínio.

Para o diabásio, os valores dos ETR apresentam uma distribuição com valores mais amplos, com [La/ $\mathrm{Yb}=4,59]_{\mathrm{N}}$, fracas anomalias negativas de Eu, com $\left[\mathrm{Eu} / \mathrm{Eu}^{*}=0,09\right]_{\mathrm{N}}$, e um comportamento simétrico e paralelo definido pelo valor da relação $\mathrm{Ce} / \mathrm{Sm}=1,65$ e $\mathrm{Gd} / \mathrm{Yb}=1,68$.
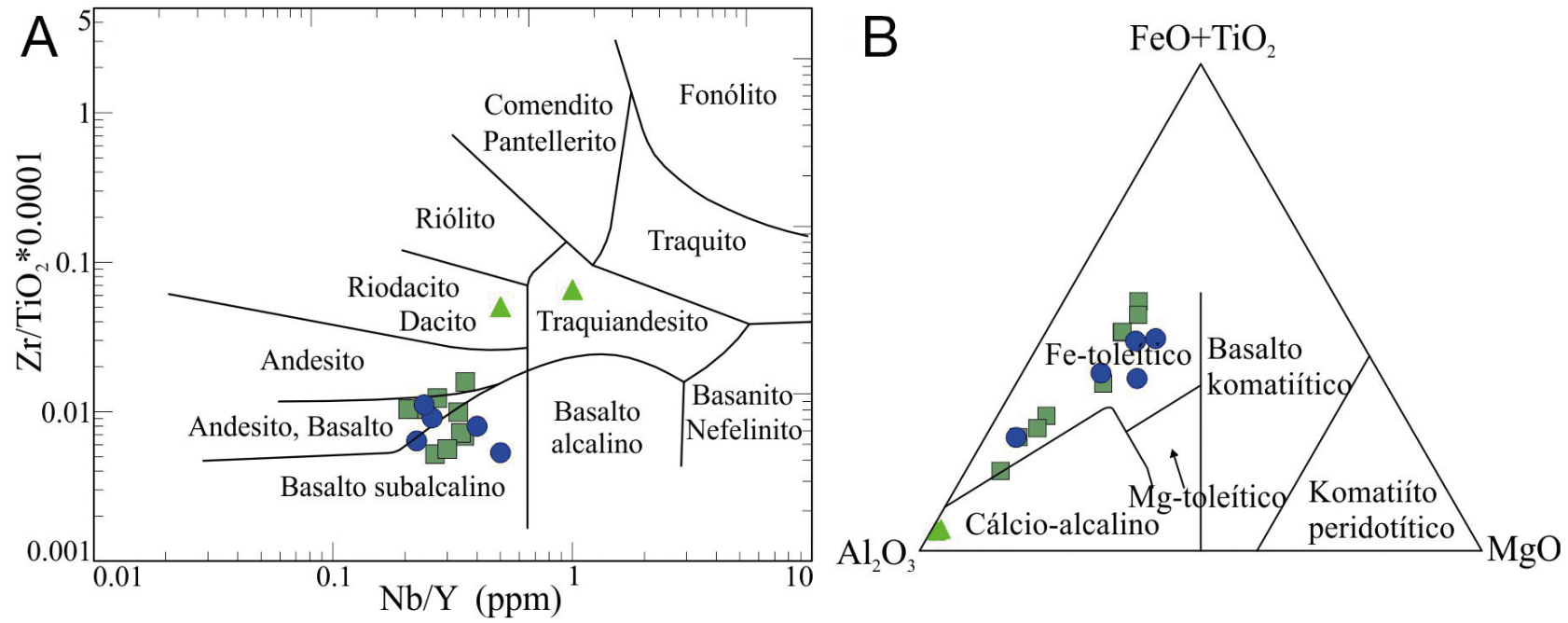

Figura 9. Diagramas de classificação, aplicadas às rochas da Sequência Magmática Gabro-Anortosítica da Serra da Alegria. (A) Winchester e Floyd (1977); (B) Jensen (1976). Gabro (O), Anortosito (^), Diabásio ( $\square$ ).
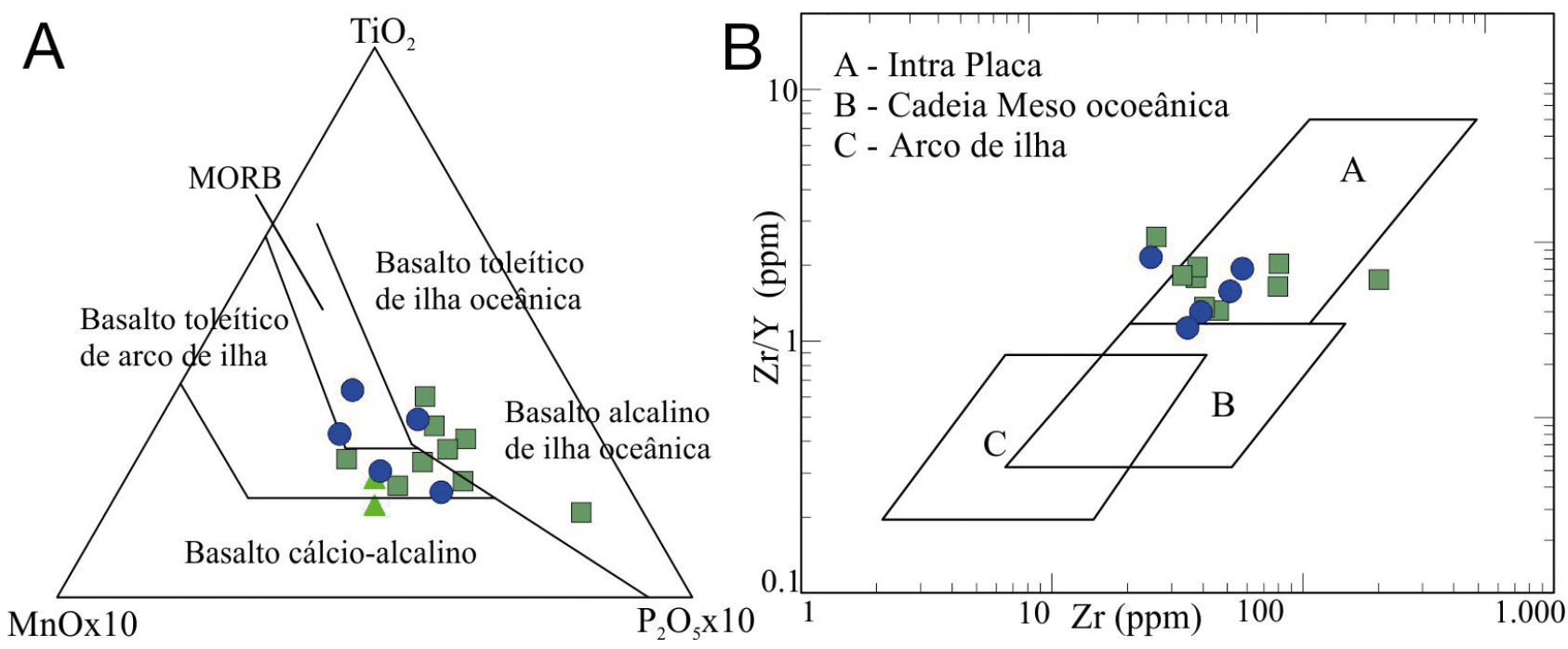

Figura 10. Diagramas de classificação tectônica, aplicadas às rochas da Sequência Magmática Gabro-Anortosítica da Serra da Alegria. (A) Mullen (1983); (B) Pearce e Norry (1979). Gabro (O), Anortosito (A), Diabásio ( $\square$ ). 


\section{CONCLUSÕES}

A Sequência Magmática da Serra da Alegria constitui o conjunto litológico do segmento norte do Batólito Alumiador e é representada por duas séries magmáticas diferenciadas independentes, uma denominada de Sequência Magmática Ácida-Intermediária da Serra da Alegria, caracterizada pelo Granito Serra da Alegria, e a outra, com enfoque principal dessa abordagem, de composição básica-ultrabásica, denominada de Sequência Magmática Gabro-Anortosítica da Serra da Alegria.

A fase de composição intermediária-ácida domina a região central do batólito e é composta de várias intrusões circulares menores de composição ácida, constituídas principalmente de microgranito, parcialmente envoltos em menores em menores proporções por rochas subvulcânicas básicas.

A fase de composição básica-ultrabásica é definida pelas intrusões de rochas diferenciadas cumuláticas, ocorrendo principalmente dispostas lateralmente ao conjunto ácido, nas áreas marginais externas e nos sopés da serra, na forma de extensos afloramentos. A parte exposta da intrusão básica é constituída dominantemente de gabro que gradam em direção às partes basais para mela gabro e raro piroxenito. Para a parte superior os gabros gradam para leuco gabro, quartzo gabro e anortosito, bem como ocorrem com maior frequência variedades de leuco pegmatito básico.

Os minerais essenciais estudados por química mineral da sequência diferenciada cumulática foram piroxênio e plagioclásio, e os minerais acessórios, os óxidos de ferro-titânio. Os minerais magmáticos identificados correspondem a andesina-labradorita, apresentando teor de anortita entre $\mathrm{An}_{36,76}-\mathrm{An}_{58,06}$ e clinopiroxênio cálcico do tipo augita e tipo ferro-augita. Os óxidos de ferro ocorrem na forma predominante de ferromagnetita, com valores de $\mathrm{FeO}^{t}$ entre 88,03 e $92,98 \%$, e titanomagnetita, com valores de $\mathrm{TiO}_{2}$ entre 1,13 e 6,39\%; já a fase subordinada é constituída de vanádio magnetita, com valores de $\mathrm{V}_{2} \mathrm{O}_{5}$ entre 0,75 e $0,98 \%$, e ilmenita. Não foi observada martitização (oxidação) de magnetita em hematita.

A possibilidade de formação de um depósito magmático cumulado básico estratiforme semiconcordante é associada às camadas de magnetita gabro e de magnetitito. Nestas ocorrem concentrações de óxidos de ferro na forma de cumulus, predominando magnetita enriquecida em óxidos de ferro. Nos litotipos da Serra da Alegria, observam-se paragêneses metaígneas estáveis apresentando transformações principalmente de hidratação, com o desenvolvimento de paragêneses para a fácies dos xistos verdes baixo, de idade neoproterozoica.

A evolução magmática da Serra da Alegria sugere a geração a partir de dois magmas sin a pós-orogênicos em ambiente tectônico de arco magmático a intraplaca: um magma ácido, gerado por fusão de rochas da crosta inferior, e um outro, constituído de magma mantélico primário, diferenciado, de composição básica, que, aliado a processos de diferenciação por cristalização e segregação fracionada, gera variedades de gabros e diabásios de composições Fe-toleíticas e diferenciados anortosíticos.

\section{AGRADECIMENTOS}

Ao apoio do Conselho Nacional de Desenvolvimento Científico e Tecnológico (CNPq), processo Bolsa PQ, $\mathrm{n}^{\circ}$ 304614/2017-3.
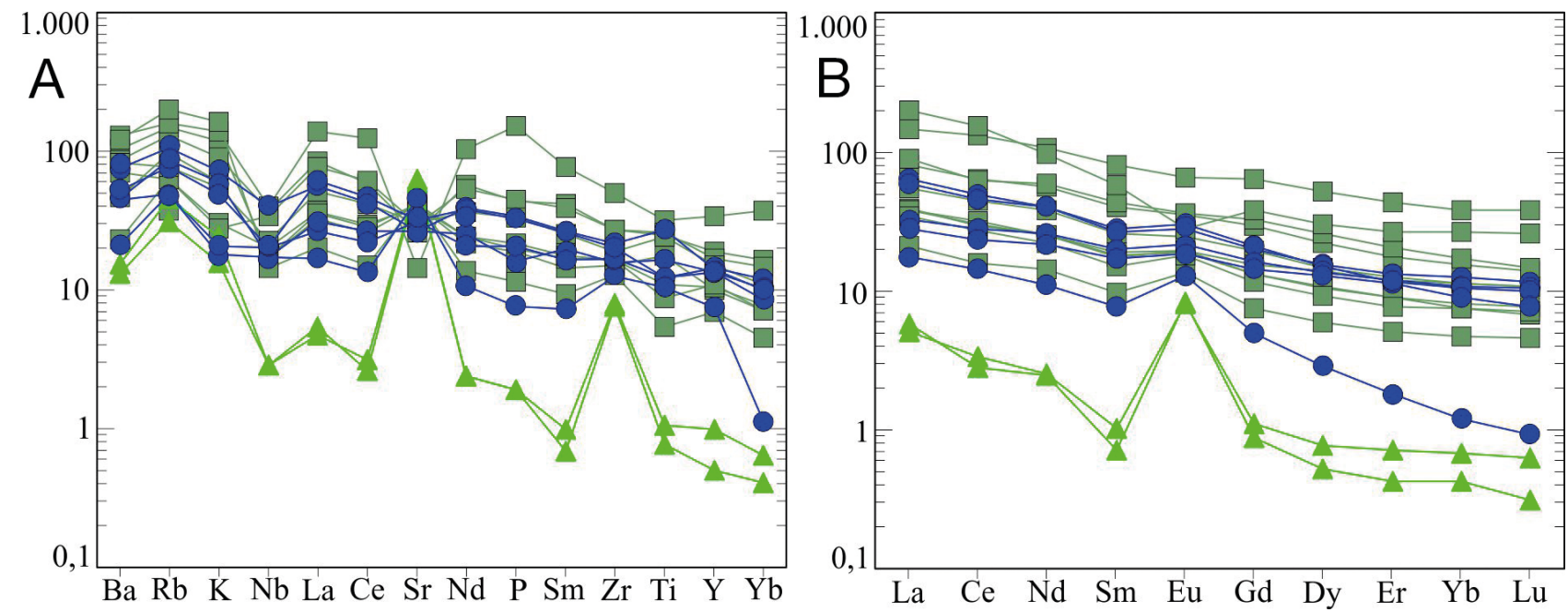

Figura 11. Diagramas de elementos incompatíveis (Spider), aplicadas às rochas da Sequência Magmática GabroAnortosítica da Serra da Alegria e normalizados segundo os valores. (A) Weaver e Tarney (1984) com os valores para a crosta inferior. (B) Boynton (1984) com os valores para meteoritos condríticos. Gabro (O), Anortosito (A), Diabásio ( $\square$ ). 


\section{REFERÊNCIAS}

Araújo, H. J. T., Neto, A. S., Trindade, C. A. H., Pinto, J. C. A., Montalvão, R. M. G., Dourado, T. D. C., Palmeira, R. C. B., Tassinari, C. C. G. (1982). Projeto RadamBrasil, Levantamento dos Recursos Naturais. Folha SF. 21 - Campo Grande. Geologia. Rio de Janeiro: MME/SG. p. 23-124.

Boynton, W. V. (1984). Geochemistry of the rare earth elements: meteorite studies. In: P. Hendersen (Ed.), Rare earth element geochemistry (v. 2, p. 63-114). Amsterdã: Elsevier. https://doi.org/10.1016/B978-0-444-42148-7.50008-3

Cordani, U. G., Teixeira, W., Tassinari, C. C. G., Coutinho, J. M. V., Ruiz, A. S. (2010). The Rio Apa Craton in Mato Grosso do Sul (Brazil) and northern Paraguay: Geochronological Evolution, Correlations and Tectonic Implications for Rodínia and Gondwana. American Journal of Science, 310(9), 9811023. https://doi.org/10.2475/09.2010.09

Corrêa, J. A., Correia Filho, F. C. L., Scislewski, G., Neto, C., Cavallon, L. A., Cerqueira, N. L. S., Nogueira, V. L. (1976). Projeto Bodoquena: Relatório Final. Goiânia: Convênio DNPM/CPRM.

Correia Filho, F. C. L., Martins, E. G., Araújo, E. S. (1981). Projeto Rio Apa: Relatório da Área I. Goiânia: Convênio CODESUL/CPRM.

Faleiros, F. M., Pavan, M., Remédio, M. J., Rodrigues, J. B., Almeida, V. V., Caltabeloti, F. P., Pinto, L. G. R., Oliveira, A. A., Pinto de Azevedo, E. J., Costa, V. S. (2015). Zircon $\mathrm{U}-\mathrm{Pb}$ ages of rocks from the Rio Apa Cratonic Terrane (Mato Grosso do Sul, Brazil): New insights for its connection with the Amazonian Craton in pre-Gondwana times. Gondwana Research, 34, 187-204. https://doi. org/10.1016/j.gr.2015.02.018

Godoi, H. O., Martins, E. G. (1999). Programa de Levantamentos Geológicos Básicos do Brasil -Folha SF.21, Campo Grande: escala 1:500.000. Brasília: CPRM.

Godoi, H. O., Martins, E. G., Mello, J. C. R. (2001). Programa Levantamentos Geológicos do Brasil - PLGB. Corumbá - Folha SE.21-Y-D, Aldeia Tomázia - Folha SF.21-V-B, Porto Murtinho -Folha SF.21-V-D, Estado de Mato Grosso do Sul. Escala 1:250.000. Brasília: CPRM/ DIEDIG/DEPAT.

Godoy, A. M., Manzano, J. C., Araújo, L. M. B., Godoy, L. P. (2014). Magmatismo da Serra da Alegria, Grupo Amonguijá, Maciço Rio Apa, sudoeste do estado do Mato Grosso do Sul. Geociências, 33(4), 558-578.
Godoy, A. M., Manzano, J. C., Araújo, L. M. B., Silva, J. A. (2009a). Contexto Geológico e Estrutural do Maciço Rio Apa, sul do Cráton Amazônico-MS. Geociência, 28(4), 485-499.

Godoy, A. M., Manzano, J. C., Araújo, L. M. B., Silva, J. A., Chaguri, G. F. (2009b). Sequência Magmática Serra da Alegria, sul do Cráton Amazônico - MS. IX Simpósio de Geologia do Sudeste. São Pedro: SBG. CD-ROM.

Godoy, A. M., Ruiz, A. S., Manzano, J. C., Araújo, L. M. B., Silva, A. J. (2010). Suíte Vulcânica Serra da Bocaina, Grupo Amonguijá, Maciço RioApa-MS. Geociências, 29(4), 519-535.

Godoy, A. M., Ruiz, A. S., Manzano, J. C., Ruiz, L. M. B. A., Montano, L. F., Sousa, M. Z. A., Batata, M. E. F., Silva, M. V. V., Baldim, I., Lima, G. A. (2006). Aspectos petrográficos e litogeoquímicos da Suíte Intrusiva Alumiador, Maciço Rio Apa, sul do Cráton Amazônico - MS. XLIII Congresso Brasileiro de Geologia. Aracaju: SBG.

Jensen, L. S. (1976). A new cation plot for classifying sub alkaline volcanic rocks. Ontario Division of Mines. Miscellaneous Paper, 66, 22 p.

Lacerda Filho, J. V. (2015). Bloco Rio Apa: Origem e Evolução Tectônica. Tese (Doutorado). Brasília: Instituto de Geociências, Universidade de Brasília.

Lacerda Filho, J. W., Brito, R. S. C., Silva, M. G., Oliveira, C. C., Moreton, L. C., Martins, E. G., Lopes, R. C., Lima, T. M., Larizzatti, J. H, Valente, C. R. (2006). Geologia e Recursos Minerais do Estado de Mato Grosso do Sul. Convênio MME/CPRM-MS. Brasília: MME/CPRM-MS.

Malagutti, M. I. A., Bahia Filho, O., Moreno, M. M. T., Nardy, A. J. R. (1998). Determinação de elementos terras raras e ítrio em rochas silicáticas por ICP-AES com separação em resina trocadora de íons. Geochimica Brasiliensis, 12(2), 75-80.

Manzano, J. C., Godoy, A. M., Araújo, L. M. B., Godoy, L. P. (2012). Suíte Plutônica Alumiador, Grupo Amonguijá, Maciço Rio Apa - MS. Geociências, 31(3), 351-370.

Morimoto, N. (1990). Nomenclatura de piroxênios. Tradução do original em inglês "Nomenclature of Pyroxenes" Garda, G. M., Atencio, D. Revista Brasileira de Geociências, 20(14), 318-328. https://doi.org/10.25249/0375-7536.1990318328

Mullen, E. D. (1983). $\mathrm{MnO} / \mathrm{TiO}_{2}, \mathrm{P}_{2} \mathrm{O}_{5}$ : a minor element discriminant for basaltic rocks of oceanic environments and its implications for petrogenesis. Earth and Planetary Science Letters, 62(1), 53-62. https://doi.org/10.1016/0012-821X(83)90070-5 
Nogueira, S. F., Sousa, M. Z. A., Ruiz, A. S., Batata, M. E. F., Cabrera, R. F., Costa, J. T. (2013). Granito Aquidabã, Suíte Intrusiva Alumiador, Sul do Cráton Amazônico, Geologia, Petrografia e Geoquímica. XIII Simpósio de Geologia da Amazônia. Belém: SBG. CD-ROM.

Pavan, M., Caltabeloti, F. P., Rodrigues Pinto, L. G. R. (2014). Carta Geológica Folha Fazenda Santa Otilia - SF.21-V-D-III. Escala 1:100.000, Estado de Mato Grosso do Sul. Brasília.

Pearce, J. A., Norry, M. J. (1979). Petrogenetic implications of Ti, $\mathrm{Zr}, \mathrm{Y}$ and $\mathrm{Nb}$ variations in volcanic rocks. Contributions to Mineral and Petrology, 69, 33-47. https://doi.org/10.1007/bf00375192

Ruiz, A. S., Simões, L. S. A., Brito-Neves, B. B. (2005). Maciço Rio Apa: extremo meridional do Cráton Amazônico. X Simpósio de Estudos Tectônicos, 301-304. Curitiba: SBG.

Silva, E. L. (1998). Geologia da região da Serra da Alegria, extremo sul do Cráton Amazônico, município de Porto Murtinho-MS. Dissertação (Mestrado). São Paulo: Instituto de Geociências, Universidade de São Paulo.
Silva, M. G., Brito, R. S. C., Lacerda Filho, J. V. (2007). Rochas graníticas do complexo Rio Apa e da Suíte Amonguijá, Mato Grosso do Sul: evidências de terrenos acrescionários paleoproterozoicos, na porção sudoeste do Cráton Amazônico. X Simpósio de Geologia do Centro Oeste. Pirenópolis: SBG. CD-ROM.

Silva, M. G., Brito, R. S. C., Lacerda Filho, J. V. (2008). Magmatismo básico-ultrabásico na Província Rio Apa, MS: implicações tectônicas e metalogenética. XLIV Congresso Brasileiro de Geologia. Curitiba: SBG. CD-ROM.

Weaver, B., Tarney, J. (1984). Empirical approach to estimating the composition of the continental crust. Nature, 310, 575577. https://doi.org/10.1038/310575a0

Winchester, J. A., Floyd, P. A. (1977). Geochemical discrimination of different magma series and their differentiation products using immobile elements. Chemical Geology, 20, 325-343. https://doi. org/10.1016/0009-2541(77)90057-2 